\title{
WYKORZYSTANIE ŚRODOWISKA NATURALNEGO W POLSKICH PLANACH PRZYSZŁEJ WOJNY W LATACH TRZYDZIESTYCH XX W.
}

Józef Piłsudski: „korytarze, wklęśnięcia i wypukłości linii granicznej przedstawiają jedno z wielkich niebezpieczeństw [...] Granice nasze dają możność wszelkich i bardzo urozmaiconych kombinacji dla napaści nieprzyjaciela”.

Zarys dziejów wojskowości polskiej (1864-1939), red. P. StaweCKi, Warszawa 1990, s. 522

\section{Wprowadzenie}

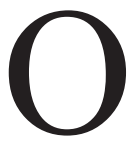

dzyskanie niepodległości przez Polskę po I wojnie światowej oraz określenie granic państwa ${ }^{1}$ spowodowało konieczność podjęcia prac sztabowych na rzecz opracowania planów militarnych dotyczących groźby przyszłych konfliktów. Jednym z ważnych elementów w prowadzeniu tych prac było również odpowiednie wykorzystanie warunków naturalnych (środowiska naturalnego). Jak rozumieć pojęcie: środowisko naturalne? Współczesne nam definicje, używając zamiennie terminu środowisko naturalne lub przyrodnicze, zakładają, że jest to:

${ }^{1}$ Warto zwrócić uwagę na rozważania dotyczące ewolucji pojęcia "granica” z perspektywy rozumienia jej naturalnego i sztucznego charakteru, autorstwa Marka Barwińskiego. Vide: M. BARwiŃSKI, Kształtowanie się granic Polski po I wojnie w aspekcie geograficznym, https://archiwum.men.gov. pl/wp-content/uploads/2018/08/zal.-4-1.pdf [dostęp: 11 IV 2019 r.]. 
ogół elementów ożywionych i nie ożywionych przyrody, które oddziałują w ciągłej interakcji ze sobą nawzajem, a także z człowiekiem, który żyje w ich obrębie i ma na nie wpływ [...] to twór natury w mniejszym czy większym stopniu przekształcony jednak przez człowieka².

Do elementów nieożywionych, które ze względu na charakter analiz wpisują się w podjętą tematykę artykułu należą: atmosfera - powietrze, opady atmosferyczne, nasłonecznienie, temperatura i wilgotność powietrza, wiatr (ruch powietrza), ciśnienie atmosferyczne; litosfera - gleba, skały, rzeźba terenu, budowa geologiczna i hydrosfera: wody powierzchniowe i podziemne ${ }^{3}$.

Z militarnego punktu widzenia w planowaniu działań wojennych ważnym elementem jest ukształtowanie terenu (na co wpływ ma środowisko naturalne, a szczególnie litosfera i hydrosfera). Teren pomaga lub przeszkadza w prowadzeniu działań militarnych każdej ze stron konfliktu. Pokrycie terenu stanowią przedmioty naturalne i sztuczne. Do naturalnych zalicza się te powstałe w wyniku oddziaływania czynników przyrodniczych, jak lasy, zarośla, łąki, rzeki czy jeziora. Do sztucznych - obiekty powstałe dzięki pracy ludzi. Na szczeblu operacyjnym ocena terenu polega na charakterystyce jego cech: ukształtowania powierzchni i infrastruktury, które wpływają na warunki prowadzenia działań bojowych ${ }^{4}$. W przypadku warunków atmosferycznych przyjęty przez Niemców w 1939 r. letnio-jesienny termin agresji na Polskę nie sprzyjał podniesieniu walorów obronnych Polski, tym bardziej że lato w tym roku było ciepłe i suche. We wrześniu temperatura $\left({ }^{0} \mathrm{C}\right)$ - wahała się od 20-22 stopni na wschodzie kraju, przez 22-23 stopnie w centrum, do 23-24 stopni na zachodzie. W najcieplejszym dniu - 9 września sięgała ona 29 stopni w centralnej Polsce. Chłodniejszy był dopiero schyłek drugiej i trzeciej dekady września ${ }^{5}$. Pogoda nie miała deszczowego charakteru, co nie ograniczało działań Luftwaffe i tempa przemieszczania się wojsk niemieckich.

${ }^{2}$ https://www.ekologia.pl/wiedza/slowniki/leksykon-ekologii-i-ochrony-srodowiska/srodowisko-naturalne [dostęp: 11 IV 2019 r.].

3 Ibidem.

4 S. Maksimiec, Armia „Lublin” we wrześniu 1939 roku, Warszawa 2006, s. 121. Na działania bojowe wpływ mają trzy elementy ukształtowania terenu: wysokość bezwzględna nad poziom morza, wysokości względne form rzeźby terenu i spadki ich zboczy. Vide: Warunki terenowe i klimatyczne Polski (sygn. Szt. Gen. 1023/81), cz. 1. Ukształtowanie terenu, Warszawa 1981, s. 7. Współczesne pole walki uwzględnia szersze rozumienie środowiska przyrodniczego, którego elementem jest człowiek. W rezultacie realizuje się, dzięki zmianom technologicznym, „walkę z dystansu” z wykorzystaniem broni precyzyjnej, systemów artyleryjsko-rakietowych o zwiększonym zasięgu, bezzałogowców, pocisków manewrujących, czy poprzez zastosowanie cyberataku. Spojrzenie na te kwestie z perspektywy NATO przedstawia szerzej np. M. Trochimiuk, Wojskowa ocena terenu oraz jej wsparcie geograficzne, „Obronność. Zeszyty Naukowe Wydziału Zarząadzania i Dowodzenia Akademii Sztuki Wojennej" 2016, nr 1 (17).

51 września 1939 r. pogodnie i gorąco, https://www.twojapogoda.pl/wiadomosc/2009-09-01/ 1-wrzesnia-1939-r-pogodnie-i-goraco_1594291/ [dostęp: 29 V 2019 r.]. 
Na temat specyfiki ukształtowania ziem II Rzeczypospolitej (RP) powstało już wiele opracowań, pisało o tym wielu geografów, analityków politycznych i wojskowych. Na uwagę zasługują prace Romana Umiastowskiego ${ }^{6}$, Leona Wasilewskiego ${ }^{7}$, Jerzego Niezbrzyckiego ${ }^{8}$ Stanisława Srokowskiego ${ }^{9}$, Władysława Sikorskiego $^{10}$ oraz uważanego za jednego z ojców polskiej geopolityki Eugeniusza Romera. Ten ostatni w swych analizach podkreślał m.in. rolę i znaczenie rzek, dorzeczy i akwenów wodnych dla rozwoju państw. Argumentował przy tym, że o integralności terytorium Polski decyduje przede wszystkim system rzeczny, który stanowi „naturalną granicę”11. E. Romer uważał, że człowiek nie jest w stanie zanegować praw natury. O znaczeniu obszaru militarnego pisał: „[...] co prawda, zorganizowana wola ludzka jest w stanie je naruszyć, ale, prędzej czy później, zwłaszcza w czasach »zawieruchy dziejowej«, przestrzeń powraca w swoje "naturalne tory«"12. Geografowie jako ważny element stanowiący o aspektach obronnych, szczególnie obszarów pogranicza, wskazują na elementy kulturowo-etniczne, zwłaszcza w państwach wielonarodowych, a do takich należała II RP. Ze względu na możliwości wydawnicze autor nie będzie rozwijał tego tematu w prezentowanym opracowaniu, koncentrując się na założeniach operacyjnych.

Przyjęty w artykule układ chronologiczny obejmuje okres od drugiej połowy lat trzydziestych XX w. (po śmierci marszałka Józefa Piłsudskiego w 1935 r.) do wybuchu II wojny światowej. Wśród opracowań dotyczących przyszłej wojny pod uwagę należy wziąć dwa najważniejsze: „Plan operacyjny Wschód” i „Plan operacyjny Zachód"13. Nie oznacza to jednak braku innych rozwiązań planistycznych, dotyczących szczegółowego wykorzystania środowiska naturalnego, które miały wzmocnić bezpieczeństwo Polski. Prace prowadzone były w dużej tajemnicy, a o ich ostatecznym kształcie wiedziało niewiele osób. W pracach uczestniczył pełniący funkcję szefa Oddziału III Operacyjnego Sztabu Głównego (SG) płk dypl. Józef Jaklicz (październik 1935 r. - marzec 1939), który następnie został

${ }^{6}$ R. Umiastowski, Terytorium Polski pod względem wojskowym, Warszawa 1921; IDEM, Podstawy obrony państwa. I - Przyrodzone podstawy obrony państwa. II - Zagadnienia komunikacji z punktu widzenia obrony państwa, Warszawa 1922; IDEM, Geografia wojenna Rzeczypospolitej Polskiej i ziem ościennych, Warszawa 1924; Granice polityczne, naturalne i obronne w czasie pokoju i wojny, KrakówDębniki 1925. Vide: P. EBerHARdT, Roman Umiastowski - zapomniany polski geograf, „Acta Universitatis Lodziensis. Folia Geographica Socio-Oeconomica" 2014, t. XVII, s. 147-160.

7 L. WASILEWSKI, Wschodnia granica Polski, „Bellona” 1925, t. VII, nr 2, s. 125-135.

${ }^{8}$ Vide: J. Niezbrzycki, Polesie. Opis wojskowo-geograficzny i studium terenu, Warszawa 1930.

9 Vide: S. SRokowsкi, Prusy Wschodnie. Kraj i ludzie, Warszawa 1929.

10 Vide: W. SıкоRsкi, Polesie jako węzet strategiczny naszego frontu wschodniego, Warszawa 1924.

${ }^{11}$ E. Romer, Polska. Ziemia i Państwo, Kraków 1917; IDEM, Ziemia i państwo. Kilka zagadnień geopolitycznych, Lwów-Warszawa 1939.

12 E. Romer, Ziemia i państwo..., t. I-II.

${ }_{13}$ Zachowane materiały archiwalne, szczególnie dotyczące Planu „Wschód”. Vide: R. Szubański, Plan operacyjny „Wschód”, Warszawa 2010, s. 5. 
mianowany II zastępcą szefa SG. Obok niego, w pracach uczestniczył jego następca na stanowisku szefa Oddziału III SG, płk dypl. Stanisław Kopański ${ }^{14}$, szef Oddziału II SG płk Marian Józef Smoleński (wcześniej płk Tadeusz Pełczyński) oraz (czasowo) płk dypl. Andrzej Marecki ${ }^{15}$ i mjr dypl. Leon Mikołaj Korwin-Nowosilski ${ }^{16}$ i oczywiście ówczesny szef SG gen. bryg. Wacław Stachiewicz ${ }^{17}$. Ważną rolę w całym procesie przygotowania planów obronnych odegrał Inspektorat Saperów SG, Naczelne Dowództwo Saperów i Szefostwo Fortyfikacji, na czele z gen. bryg. Mieczysławem Dąbkowskim ${ }^{18}$ oraz Wojskowy Instytut Geograficzny, którego szefem od 1935 r. był płk dypl. Tadeusz Zieleniewski (w Instytucie tym opracowywano mapy poszczególnych regionów kraju, określano współrzędne terenu szczególnie istotne dla artylerii i lotnictwa) ${ }^{19}$.

Biorący udział w pracach nad obydwoma planami płk J. Jaklicz zauważał, że problem zagrożenia militarnego ze strony zachodniego i wschodniego sąsiada Polski nasilił się w 1938 r. Po wkroczeniu oddziałów polskich na teren Zaolzia, Związek Radziecki ogłosił mobilizację korpusów granicznych, czym tłumaczono przyspieszenie prac nad Planem „Wschód”:

Dlatego główny wysiłek operacyjny [wspominał płk Jaklicz - A.W.] szedł w kierunku stworzenia jak najszybciej gotowości, dla odparcia najazdu wschodniego. Nie znaczy to, aby Zachód był zaniedbywany [...]. Przygotowania operacyjne na Zachodzie ruszyły w tempie przerastającym, zdawałoby się, techniczne, ludzkie możliwości, w marcu 1939 r., gdy zagrożenie stało się niewątpliwe. Trwały dosłownie do chwili pierwszego niemieckiego bombardowania. Lecz, jako oficer biorący w nich bezpośredni udział, stwierdzam, że Plan zachodni posunął się dokumentalnie dalej, niż Plan Wschodni po okresie 3-letniej nad nim pracy. Jeżeli był stracony czas, to odzyskano go potrójnym wysiłkiem ${ }^{20}$.

14 Vide: S. Kopański, Moja służba w Wojsku Polskim 1917-1939, Londyn 1965, s. 267-268. Płk Stanisław Kopański ciekawie pisze o całym procesie decyzyjnym w WP w 1939 r. (s. 297-298).

${ }^{15}$ Instytut Polski i Muzeum im. gen. Sikorskiego, sygn. B.I.7.c, Relacja płk. dypl. Andrzeja Mareckiego.

${ }^{16}$ Instytut Polski i Muzeum im. gen. Sikorskiego, sygn. B.I.10.b, Relacja mjr. dypl. Leona M. Korwina-Nowosilskiego.

17 J. JAKLICZ, A więc wojna! Kampania wrześniowa 1939 oraz inne pisma i wspomnienia, Warszawa 2016, s. 200.

${ }_{18}^{18}$ Instytut Polski i Muzeum im. gen. Sikorskiego, sygn. B.I.1c, Naczelne Dowództwo Saperów.

${ }_{19}$ Instytut Polski i Muzeum im. gen. Sikorskiego, sygn. B.I.12.f, Ministerstwo Spraw Wojskowych - Wojskowy Instytut Geograficzny.

${ }^{20}$ Ibidem, s. 67. Płk J. Jaklicz zauważał, że do końca 1938 r. całokształt prac nad planami przyszłej wojny koncentrował się na wojnie z Rosją. Prace nad Planem „Zachód” były na etapie konsultacji Generalnego Inspektora - marszałka E. Rydza-Śmigłego z inspektorami armii w postaci przygotowywania konkretnych studiów. Instytut Polski i Muzeum im. gen. Sikorskiego, sygn. B.I.3a, Relacja płk. dypl. J. Jaklicza, cz. 1, k. 7. Z kolei mjr dypl. Marian Utnik podkreślał, że prace nad Planem „Zachód” rozpoczęto w styczniu 1939 r. Wówczas to wyznaczono szefa Wydziału Zachód, którym 


\section{Położenie geopolityczne Polski w dwudziestoleciu międzywojennym}

\section{Kształt granic}

Granica II RP miała otwarty charakter, trudniejszy dla prowadzenia działań obronnych. Powierzchnia państwa wynosiła $389720 \mathrm{~km}^{2}$ (po zajęciu Zaolzia). Cała długość granic to $5529 \mathrm{~km}, \mathrm{w}$ tym z krajami stanowiącymi bezpośrednie zagrożenie: Niemcami - 1912 km i ZSRS - 1412 km. Graniczyliśmy również z Czechosłowacją - $984 \mathrm{~km}$, Litwą - $507 \mathrm{~km}$, Rumunią - $349 \mathrm{~km}$, Węgrami - $277 \mathrm{~km}$ (od 1939 r.), Łotwą - 109 km. Problemem był odcinek graniczny z Wolnym Miastem Gdańsk wynoszący 121 km, który również należało uwzględnić, biorąc pod uwagę zagrożenie ze strony Niemiec. Granica morska wynosiła $140 \mathrm{~km}^{21}$.

Bardzo niekorzystnie ukształtowana była granica z Niemcami: na obszarze Prus Wschodnich wynosiła ona $607 \mathrm{~km}$, a na zachodzie $1305 \mathrm{~km}$. Po utworzeniu Protektoratu Czech i Moraw wzrosło zagrożenie granicy południowej. Zajęcie w 1938 r. przez Wojsko Polskie (WP) na Zaolziu spornych obszarów Śląska Cieszyńskiego, sytuację tę nieco poprawiło. Niestety, powstanie państwa słowackiego oraz zawarcie sojusz niemiecko-słowackiego w 1939 r., groźbę tę potęgowało (pomimo wkroczenia na teren Rusi Zakarpackiej wojsk węgierskich). Efektem tego było zaatakowanie we wrześniu 1939 r. przez słowacką Armię „Bernolák” (50 tys. żołnierzy) Polski od południa. Wydarzenia z 1939 r. powodowały przesunięcie punktu ciężkości niemieckiego ataku na Polskę na kierunek południowy. Polska miała być wzięta w kleszcze z południa (Dolny Śląsk i Morawy oraz Słowacja - taran uderzeniowy i oskrzydlenie) i z północy (Prusy Wschodnie i Pomorze Zachodnie) $)^{22}$. Granica zachodnia nie posiadała naturalnych przeszkód, poza odcinkami niektórych rzek: Wisła (od okolic Kwidzyna do Białej Góry), Noteć (od Ujścia do okolic Krzyża Wielkopolskiego), Prosna (od Kuźnicy Żytniowskiej do okolic Chróścina), Liswarta (od Starokrzepis do okolic Węglowic) i Odra (od Raciborza do Olzy).

W przypadku wschodniej granicy ze Związkiem Radzieckim - na północy sięgała ona rzeki Dźwiny i biegła na zachód od Mińska, po łuku rozpiętym między rzekami Berezyną i Prypecią. Następnie przebiegała odcinkiem koło Mikaszewicz, skręcając na południowy zachód, przez Ostróg do rzeki Zbrucz i dalej do ujścia do Dniestru. Na obu krańcach występował trójstyk graniczny: polsko-łotewski-sowiecki i polsko-rumuńsko-sowiecki. Główną naturalną zaporą w przypadku granicy wschodniej były bagna poleskie rozlewające się na

został płk Marecki pracujący dotychczas w Wydziale „Wschód”. Każda z ekip przygotowujących plany wojny miała około 7 oficerów.

${ }^{21}$ P. Eberhard, Polska i jej granice. Z historii polskiej geografii politycznej, Lublin 2004, s. 127.

${ }^{22}$ J. JAKLICZ, op. cit., s. 48. 
przestrzeni od 130-350 km szerokości, które stanowiły teren o wybitnie naturalnych cechach obronnych ${ }^{23}$. Samo położenie Polski stwarzało wiele problemów dotyczących bezpieczeństwa granic państwa, do których należały: brak granic naturalnych (poza odcinkiem morskim i fragmentem górskim na południu), zbyt długa i nieregularna granica z Niemcami, mały dostęp do morza (przez korytarz wywołujący roszczenia niemieckie) oraz niebezpieczeństwo płynące ze strony Prus Wschodnich.

\section{Sojusze polityczno-militarne Polski}

Od początku lat dwudziestych XX w. Polska posiadała dwa strategiczne sojusze militarne z Francją i Rumunią. W dniu 19 lutego 1921 r. podpisano układ polityczny z Francją, uzupełniony 21 lutego ściśle tajną konwencją wojskową. W stosunku do Niemiec w konwencji wojskowej postanawiano:

Na wypadek agresji niemieckiej przeciwko jednemu z obu krajów są na równi obowiązane do udzielenia sobie tego poparcia, stosownie do wspólnego porozumienia. Za agresję niemiecką uważana będzie wszelka agresja wychodząca z terytorium podlegającemu rządowi niemieckiemu

oraz wobec agresji ze strony Związku Radzieckiego:

Francja zobowiązuje się do działania za równo na lądzie jak i na morzu celem zapewnienia Polsce w dalszym ciągu bezpieczeństwa od strony Niemiec [...] oraz udzielenia jej pomocy w obronie przeciwko armii Sowietów ${ }^{24}$.

Z kolei 3 marca 1921 r. podpisano umowę sojuszniczą z Rumunią zwróconą przeciwko Związkowi Radzieckiemu. Traktat ten - odnawiany co 5 lat - był ważny do 26 marca $1941 \mathrm{r}^{25}$ Uaktualniona konwencja (Układ Techniczny między Królestwem Rumuńskim i Rzeczpospolitą Polską) została podpisana 30 czerwca 1931 r. przez ministra Józefa Becka i gen. Tadeusza Piskora - ówczesnego szefa SG oraz szefa sztabu armii rumuńskiej gen. Nicolae Samsonovici i rumuńskiego posła w Warszawie Grigore Bilenizesku. W wypadku ataku Sowietów na jednego z sojuszników ustalono „obowiązek natychmiastowej mobilizacji i rozpoczęcia wojny, nawet $\mathrm{w}$ wypadku istnienia już stanu wojny z innym państwem”26.

${ }^{23}$ Mały Rocznik Statystyczny 1934, Warszawa 1934, s. 4.

${ }^{24}$ Źródła do historii powszechnej okresu międzywojennego, t. I, 1917-1926, red. S. SIERPOWSKI, Poznań 1989, s. 206 (tekst Ściśle tajnej konwencji wojskowej między Polską a Francją z 19 II 1921 r.).

25 Ibidem, s. 209-210 (tekst Konwencji dotyczącej przymierza odpornego między Polską a Rumunią z 3 III 1921r.).

${ }^{26}$ H. BuŁHak, Dokumenty dotyczące wojskowego sojuszu polsko-rumuńskiego 1921-1931, „Studia z Dziejów Rosji i Europy Środkowo-Wschodniej” 2008, t. XLIII, s. 48-51. Vide: H. WalczAK, 
Dopiero bezpośredni wzrost zagrożenia wojennego ze strony III Rzeszy spowodował przedstawienie Polsce gwarancji brytyjskich 31 marca 1939 r. oraz francuskich 13 kwietnia 1939 r., a także podpisanie postanowień protokołu wojskowego z Francją 19 maja 1939 r. i umowy sojuszniczej z Wielką Brytanią 25 sierpnia 1939 r. ${ }^{27}$ Tworzyło to przeświadczenie o zbrojnym wystąpieniu Francji i Wielkiej Brytanii w przypadku niemieckiego ataku na Polskę $e^{28}$. Wejście w życie protokołu wojskowego z 19 maja uzależnione było od stosownej umowy politycznej między obu państwami, która została zawarta 4 września. Niestety sojusznicy Polski przyjęli defensywny charakter prowadzenia wojny.

\section{Z kim wojna?}

Na początku lat trzydziestych została przyjęta przez Józefa Piłsudskiego, a realizowana przez Józefa Becka, koncepcja tzw. „równych odległości” pomiędzy obu agresywnie do nas nastawionymi sąsiadami ${ }^{29}$. Wynikało to z podpisania przez Polskę dwóch umów międzynarodowych: ze Związkiem Radzieckim (Pakt o nieagresji między Rzeczypospolitą Polska a ZSRR - 25 lipca 1932 r. $)^{30}$ i Niemcami (Deklaracja o niestosowaniu przemocy między Polska a Niemcami - 26 stycznia $\left.1934 \mathrm{r}^{31}\right)$.

Józef Piłsudski był realistą - w marcu 1934 r. oceniał, że:

[...] dobre stosunki między Polską i Niemcami mogą trwać, może jeszcze cztery lata ze względu na przemiany psychiczne, które dokonują się w narodzie niemieckim, za więcej lat Komendant nie ręczy ${ }^{32}$.

Przedłużenie przymierza Polski i Rumunii a kwestia rokowań o pakt o nieagresji z ZSRR (1930-1931), „Studia z Dziejów Rosji i Europy Środkowo-Wschodniej” 2008, t. XLIII, s. 35-36.

27 Źródła do historii powszechnej..., t. III, 1935-1939, red. S. Sierpowski, Poznań 1992, s. 454-457 (tekst Układu o wzajemnej pomocy między Polską a Wielką Brytanią z 25 VIII 1939 r.). W przypadku możliwości pomocy ze strony Wielkiej Brytanii były one bardzo ograniczone, raczej wiązały się one ze wsparciem Francji. W przypadku Polski użyte miało być lotnictwo: „W razie agresji niemieckiej przeciwko Polsce, lotnictwo to będzie bombardować wojskowe obiekty nieprzyjacielskie, w razie zaś bombardowania przez Niemców obiektów cywilnych w Polsce, odpowie bombardowaniem takich samych obiektów w Niemczech". W. Stachiewicz, Pisma, t. I, Przygotowania wojenne w Polsce 1935-1939, „Zeszyty Historyczne” (Paryż) 1977, z. XL, s. 35-36.

${ }_{28}$ Polskie Siły Zbrojne w II wojnie światowej, t. I, Kampania wrześniowa, cz. 1, Londyn 1951, s. 100.

${ }^{29}$ Szerzej na temat polityki „równych odległości” pisali np.: M. ZaCharias, Polska wobec zmian w układzie sił $w$ Europie w latach 1932-1936, Wrocław 1981; A.M. CienciaŁA, Polish Foreign Policy 1926-1939: Equilibeium, Stereotype and Reality, „Polish Review” 1973, vol. XX, no. 1, s. 42-58.

${ }^{30}$ Dokumenty z dziejów polskiej polityki zagranicznej 1918-1939, red. T. JĘDRUszczaK, M. NoWAK-KiєBikowa, t. I, 1918-1932, Warszawa 1989, s. 487-490 (tekst Paktu nieagresji między Rzecząpospolitą Polską a ZSRR z 25 VII 1932 r.).

31 Ibidem, t. II, 1933-1939, Warszawa 1996, s. 32-338 (Deklaracja o stosowaniu przemocy między Polską a Niemcami ze stycznia 1934 r.).

32 K. Świtalski, Diariusz 1919-1935, do druku przygotowali A. Garlicki i R. Świętek, Warszawa 1992, s. 660-661. 
W 1929 r. J. Piłsudski zatrzymał prace dotyczące wariantu wojny na dwa fronty $(\mathrm{N}+\mathrm{R})$, co było świadomą decyzją wynikającą z braku możliwości skutecznego prowadzenia dwufrontowych działań wojennych. Marszałek zakazywał wojny zaczepnej z ZSRR, co wynikało z zapewnień (tajne konwencje militarne) udzielenia pomocy Polsce jedynie w przypadku sowieckiej agresji3 ${ }^{33}$.

W dniu 12 kwietnia 1934 r. J. Piłsudski zwołał do siedziby Generalnego Inspektoratu Sił Zbrojnych (GISZ) konferencję, wyznaczając uczestnikom zadanie, polegające na odpowiedzi w ciągu miesiąca na pytanie, który „[...] z sąsiadów jest niebezpieczniejszy i który z nich może stać się wcześniej niebezpieczny. Rosja czy Niemcy?" ${ }^{44}$. W grupie ankietowanych generałów, dziewięciu uznało, że Niemcy będą groźniejsze dla Polski i mogą wcześniej zaatakować - byli to generałowie: Aleksander Osiński, Leon Berbecki, Mieczysław Norwid-Neugebauer, Juliusz Rómmel, Stefan Dąb-Biernacki, Gustaw Orlicz-Dreszer, Kazimierz Fabrycy, Stanisław Burhardt-Bukacki i Jan Kruszewski. Jedynie generałowie: Edward Śmigły-Rydz i Janusz Gąsiorowski byli przekonani o większym zagrożeniu ze strony Związku Radzieckiego. Czterech generałów wskazywało na dwa warianty: Kazimierz Sosnkowski, Tadeusz Piskor i Daniel Konarzewski podkreślali, że najpierw groźniejszy będzie ZSRR, a Tadeusz Kasprzycki, że najpierw grozi nam atak ze strony Niemców ${ }^{35}$.

W czerwcu 1934 r. w GISZ doszło do powołania Biura Studiów Strategicznych, które nazywano nieformalnie „Laboratorium”36. J. Piłsudski zadał do analizy w biurze jednoznaczne pytanie: Z kim wojna najpierw? Na szefa komórki powołano gen. dyw. Kazimierza Fabrycego, którego zwolniono z funkcji wiceministra spraw wojskowych (na jego prośbę). Celem działania „Laboratorium” miała być

${ }^{33}$ L. Moczulsкi, Wojna prewencyjna. Czy Piłsudski planował najazd na Niemcy?, Warszawa 2017, s. 22-23.

${ }^{34}$ J. Halbersztadt, Józef Piłsudski a mechanizm podejmowania decyzji wojskowych w latach 1926-1935, „Przegląd Historyczny” 1983, nr 4 (74), s. 720. Piłsudski nakazał przygotowanie odpowiedzi na ankietę w sposób samodzielny i bez konsultacji oraz pod przymusem dyskwalifikacji.

35 Vide: Archiwum Akt Nowych, Instytucje wojskowe 1918-1939, Ministerstwo Spraw Wojskowych, Gabinet Ministra. sygn. 296/III-21, Zestawienie odpowiedzi z maja 1934 r., k. 2.

${ }^{36}$ „Laboratorium” było tajną komórką specjalną, powstałą w 1934 r. i zajmującą się analizą zagrożenia politycznego i wojskowego ze strony naszych sąsiadów - III Rzesza i ZSRR. Jej działalność była krótkotrwała. Przestała istnieć w 1935 r., po śmierci J. Piłsudskiego. Vide: Wspomnienia napisane przez kierownika „Laboratorium” gen. dyw. Kazimierza Fabrycego - K. FABRYCY, Komórka specjalna (Studia polityczno-wojskowe nad Rosja i Niemcami w r. 1934), „Niepodległość” 1955, t. V; K. Glabisz, „Laboratorium”, „Niepodległość” 1958, nr 6; S. Pstrokoński, Interna, „Wiadomości” (Londyn) 1950, nr (23) 218 z 4 VIII, s. 2; P. Ko£AKowsKi, „Laboratorium”- komórka analityczna Józefa Piłsudskiego, „Słupskie Studia Historyczne” 2010, nr 16, s. 124; A. WojtaszaK, Udział Kazimierza Glabisza w pracach "Laboratorium” - specjalnej komórki przewidywania działań wojennych, [w:] Problemy historii wojskowości w kraju i na obczyźnie po wrześniu 1939 roku. Studium historyczne i politologiczne. Tom dedykowany pamięci nestora historyków polskich profesora Józefa Janowskiego (1906-2009), red. L. Nowak, M. Szczerbiński, G. Wieczorek, Gorzów Wielkopolski 2010 i inne. 
analiza sytuacji w państwach sąsiednich, czyli monitorowanie wzrostu zagrożenia dla Polski oraz wzmożona działalność wywiadowcza ${ }^{37}$. W listopadzie tego roku doszło z inicjatywy GISZ do konferencji w „Laboratorium”. Wygłoszone zostały dwa referaty przez gen. Kazimierza Fabrycego i ppłk. Kazimierza Glabisza. Puenta obu wystąpień, dotycząca możliwych zagrożeń ze strony naszych sąsiadów, była w obu przypadkach podobna: „[...] wcześniej niebezpieczne będą Niemcy"38. Podsumowujący konferencję J. Piłsudski miał powiedzieć, że obecnie niebezpieczniejszy jest Związek Radziecki, bo jest bardziej nieobliczalny, co nie oznacza, że zagrożenie ze strony Niemiec można lekceważyć. Z kolei nieoficjalnie miał powiedzieć ppłk. K. Glabiszowi: „Ja nikomu prawie nie ufam, a co dopiero Niemcom. Muszę jednak grać, bo Zachód jest obecnie parszywieńki. Jeżeli niebawem nie przejrzy i nie stwardnieje, będzie trzeba się przestawić w pracach" ${ }^{39}$. Marszałek podkreślał konieczność ciągłej weryfikacji zagrożeń ze strony sąsiadów Polski ${ }^{40}$.

Śmierć J. Piłsudskiego oznaczała kres działania „Laboratorium”. Wniosek końcowy, który gen. Fabrycy wysłał do GISZ był następujący: „Uważam, że wszelkie warunki do sojuszu niemiecko-sowieckiego już istnieją"41.

\section{Ukształtowanie terenów II Rzeczypospolitej a przyszła wojna}

\section{Uwarunkowania ukształtowania terenu na wschodzie}

Powojenny kształt granic wschodnich II RP stwarzał wiele problemów. Największym z nich był brak kontroli nad tzw. Bramą Smoleńską, przez którą prowadził szlak ze wschodu na zachód - teren ten znalazł się w całości w granicach Związku Radzieckiego. Z geograficzno-wojskowego punktu widzenia należało brać pod uwagę istotną przeszkodę naturalną, jaką było Polesie (vide tabela 1). Na północy granicę pomiędzy Polską, Litwą i ZSRR stanowił tzw. „występ wileński”, który był strategicznie "martwy”. Pozostałe ziemie, na południe od tego obszaru, ze względu na znajdującą się tam naturalną przeszkodę (tzw. „błota poleskie”), dzielono na część białoruską i ukraińską ${ }^{42}$. Znaczenie Polesia wyraźnie podkreślał gen. Władysław Sikorski, pisząc:

37 K. Glabisz, op. cit., s. 220.

38 A. WoźnY, Niemieckie przygotowania do wojny z Polska w ocenach polskich naczelnych władz wojskowych w latach 1933-1939, Warszawa 2000, s. 27.

39 K. FABrycy, op. cit., s. 219-220. Marszałek miał dodać: „Musiałem was skrytykować, choć mieliście dużo racji. Przychylenie się do waszych wywodów na tak licznym zebraniu zostałoby przez panikarzy nawet przy odrzuceniu waszych wniosków końcowych źle zrozumiane. Ja nikomu prawie nie ufam, a cóż dopiero Niemcom".

40 K. Glabisz, op. cit., s. 225.

41 S. Pstrokoński, op. cit., s. 2.

42 A. Rzepniewski, Wojsko Polskie wobec perspektywy zagrożenia wojennego (13 maja 1935 - 31 sierpnia 1939), cz. I, Warszawa 1992, s. 52. 
Polesie przez długi jeszcze okres czasu i niezależnie od postępów techniki wojennej stanowić będzie pierwszorzędną zaporę wojenną. Olbrzymie bagna i lasy, niezmierzone przestrzenie, pozbawione zdatnych do użytku dróg i komunikacji, wpływać będą zawsze na ruchy wojsk ${ }^{43}$.

Pomiędzy Polesiem a pasmem Karpat rozciągała się dolina Dniestru. Przez ten obszar przebiegały trzy szlaki: Wołoski (Brama Przemyska), Kuczmański i Czarny (Brama Wołyńska). Na północ od Polesia istniał Korytarz Słucki, którego naturalnym przedłużeniem był szlak z Wilna i Mińska w kierunku wspomnianej tzw. Bramy Smoleńskiej. Istniała również brama z Wilna do Pskowa, która przebiegała przez Dźwinę w okolicach Połocka. Na tym obszarze znajdowały się trakty z Wilna i Kowna do Inflant oraz przebiegała droga z Gdańska i Królewca do Rygi ${ }^{44}$.

Tabela 1

Teren pogranicza polsko-sowieckiego pod kątem przyszłej wojny

\begin{tabular}{|l|l|}
\hline Odcinek granicy & \multicolumn{1}{c|}{ Po stronie Polski } \\
\hline $\begin{array}{l}\text { Występek wileń- } \\
\text { ski i białoruski } \\
\text { teatr operacyjny }\end{array}$ & $\begin{array}{l}\text { Najważniejsze naturalne przeszkody obronne to górny bieg rzek } \\
\text { Niemna i Szczary, z bagnami oraz z błotnistą puszczą zaniemeńską. } \\
\text { Na tym obszarze występowało szereg pojezierzy w rejonie Suwałk } \\
\text { oraz pomiędzy Dźwiną i Wilią (pojezierze wileńskie) i nad Dźwiną } \\
\text { (pojezierze inflancko-połockie). W przypadku „występku wileń- } \\
\text { skiego" istniała groźba dwustronnego okrążenia. Teren był lesisty } \\
\text { i mało skomunikowany. Wyżyna Nowogródzka, to obszar pozba- } \\
\text { wiony istotnych przeszkód naturalnych. Z trzech stron ograniczały } \\
\text { go kompleksy leśne: północnego Polesia, Puszczy Nalibockiej oraz } \\
\text { lasy wzdłuż prawego brzegu dolnej Szczary. Ważnym elementem } \\
\text { infrastruktury komunikacyjnej były dwie linie kolejowe z Barano- } \\
\text { wicz do Brześcia i Białegostoku. Główne linie zagrożenia w kierun- } \\
\text { ku Wilna mogły przebiegać z kierunku Połocka i Mińska. Niebez- } \\
\text { pieczny odcinek stanowił teren między Lidą a Grodnem. Istotną } \\
\text { rolę odgrywała głęboka dolina Niemna oraz na granicy z Litwą lasy }\end{array}$ \\
\hline
\end{tabular}

${ }^{43}$ W. Sikorski, Polesie - jako teren strategiczny, „Bellona” 1920, z. 3, s. 161-162; Polskie Sity Zbrojne..., s. 111-113.

${ }^{44}$ T. Kośmider, Planowanie wojenne w Polsce w latach 1921-1926, Toruń 2002, s. 15. 


\begin{tabular}{|c|c|}
\hline Odcinek granicy & Po stronie Polski \\
\hline & $\begin{array}{l}\text { Orańskie i Puszcza Rudnicka. Samo Wilno było skomunikowane } \\
\text { dwutorową linią kolejową z Białymstokiem, podobnie jak i Lida } \\
\text { z Wołkowyskiem. }\end{array}$ \\
\hline $\begin{array}{l}\text { Ziemie w cen- } \\
\text { trum - Polesie }\end{array}$ & $\begin{array}{l}\text { Teren o najlepszych walorach naturalnych do obrony: bagienno- } \\
\text {-leśny, bezdroża - utrudniający działania operacyjne, dzieląc je na } \\
\text { południowo i północno-wschodnie odcinki. Zasłaniał dorzecze } \\
\text { środkowej Wisły i ułatwiał działania obronne, ograniczał długość } \\
\text { linii frontu wschodniego o } 25 \text { procent. Obszar miał kształt niere- } \\
\text { gularnego trójkąta opartego o rzeki Bug i Leśna oraz wododzia- } \\
\text { ły Dniepru (pomiędzy Rogaczowem a Kijowem). Długość terenu } \\
\text { - około } 500 \text { km ( } 300 \text { km na obszarze Polski) a szerokość około } \\
200 \text { km. Obszar ten wyznaczały Wyżyna Nowogródzka (na pół- } \\
\text { nocy) oraz Wyżyna Wołyńska (na południu). Centralne miejsce } \\
\text { stanowiła bagnista dolina Prypeci oraz ciągi bagien i trzęsawisk } \\
\text { na terenach od Jasioły do północnej Słuczy, między Stochodem } \\
\text { a Styrem i wzdłuż Stwigi. Rzeki Polesia latem mogły służyć jako } \\
\text { szlaki żeglowne. Uzupełnieniem były sztuczne kanały Królewski } \\
\text { i Ogińskiego. Obszar Polesia posiadał słabą infrastrukturę drogo- } \\
\text { wą, niewielka ilość dróg (bitych), znajdował się w rejonie Brześcia } \\
\text { nad Bugiem. Istniały nieliczne szlaki kolejowe (jednotorowe), np. } \\
\text { wzdłuż granicy państwa (z Baranowicz do Równego). Obszar ten } \\
\text { był słabo zaludniony, co powodowało konieczność organizacji za- } \\
\text { plecza w postaci zaopatrzenia żywnościowego. Na tym terenie pro- } \\
\text { blemem było użycie każdego rodzaju wojsk. }\end{array}$ \\
\hline $\begin{array}{l}\text { Tereny } \\
\text { południowe }\end{array}$ & $\begin{array}{l}\text { Obszar Wołynia i Podola oraz nizin podkarpackich i pogórza. Po- } \\
\text { ważne przeszkody naturalne stanowiły dopływy Prypeci na Woły- } \\
\text { niu (przecinające teren południkowo - Słucz, Horyna i Styr) oraz } \\
\text { jary dopływów Dniestru na Podolu. W przypadku Wołynia powo- } \\
\text { dowało to ograniczenia ruchów wojsk aż po Łuck. W kierunku po- } \\
\text { łudniowym rozciągała się Wyżyna Wołyńska (Brama Wołyńska), } \\
\text { która na odcinku od Równe do Zdołbunów zwężała się do kilku- } \\
\text { dziesięciu kilometrów. Na południu teren przyjmował wyżynny } \\
\text { charakter - pasma: krzemienieckie i mizockie, pokryte nielicznymi } \\
\text { drogami, jarami i wąwozami o bagnistych dolinach. Obszar Podola } \\
\text { miał wyżynny charakter, był pokryty jarami o urwistych zboczach, } \\
\text { którymi płynęły odnogi Dniestru: Zbrucz, Seret, Kropiec, Strypa, } \\
\text { Złota i Glinna Lipa. Sam Dniestr był w wielu miejscach łatwy do }\end{array}$ \\
\hline
\end{tabular}


Tabela 1 (cd.)

\begin{tabular}{|l|l|}
\hline Odcinek granicy & \multicolumn{1}{c|}{ Po stronie Polski } \\
\hline $\begin{array}{l}\text { Tereny } \\
\text { południowe }(c d .)\end{array}$ & $\begin{array}{l}\text { ułatwiał działań operacyjnych. Obszar Pokucia i Bieszczad, ogra- } \\
\text { niczały pasma górskie Czarnohy i Gorganów. }\end{array}$ \\
\hline
\end{tabular}

* Cała granica wschodnia była podzielona przez błota Polesia na dwie części operacyjne. Część północna wynosiła $490 \mathrm{~km}$, a południowa $440 \mathrm{~km}$. Odejmując odcinek poleskich bagien, dla ochrony wschodniej granicy państwa należało przygotować około 20-22 dywizje piechoty. Vide: Wrzesień 1939. Radzieckie zagrożenie Rzeczypospolitej $w$ dokumentach, relacjach $i$ wspomnieniach, wybór i oprac. W. WŁodarkiewicz, Warszawa 2005, s. 14 (Pismo oddziału III a Biura Ścisłej Rady Wojennej „Wojskowo-polityczne podstawy do opracowań planów obrony państwa” z 17 VI 1921 r.).

Źró d to: oprac. własne na podstawie: R. SzUBAŃSkı, Plan operacyjny „Wschód”, Warszawa 2010, s. 9-14.

\section{Uwarunkowanie ukształtowania terenu na granicy z Niemcami}

Na kierunku zachodnim, na granicy z Niemcami można było wyodrębnić trzy bramy, którymi prowadziły szlaki do Polski: Brama Lubuska, Brama Łużycka i obszar w okolicach Szczecina. Odcinek południowy granicy zamykały pasma górskie Sudetów i Karpat. Przez rejon Sudetów wiedzie szereg przełęczy, a na Górny Śląsk i do Wielkopolski prowadzi Brama Morawska ${ }^{45}$. Bez wątpienia, ze względu na swój charakter, trudniejszą z punktu widzenia obronności państwa była granica z Niemcami. Ukształtowanie jej z dwóch stron od północy i zachodu, bez naturalnych osłon, a po zajęciu obszaru Czechosłowacji (15 marca 1939 r.), także na granicy południowo-zachodniej (wzrost zagrożenia dla Górnego Śląska) - problem ten jeszcze bardziej utrudniało. Powstałe w pierwszej połowie lat dwudziestych (w ramach prac Biura Ścisłej Rady Wojennej) opracowanie Ocena terenu pogranicznego pod kontem widzenia wojny $z$ Niemcami (Oddział III a), dzieliło obszar granicy polsko-niemieckiej na pięć odcinków (vide tabela 2).

Tabela 2

Teren pogranicza polsko-niemieckiego pod kątem widzenia wojny z Niemcami

\begin{tabular}{|l|l|}
\hline \multicolumn{1}{|c|}{ Odcinek granicy } & \multicolumn{1}{c|}{ Po stronie Polski } \\
\hline $\begin{array}{l}\text { Wschodnio- } \\
\text {-Pruski }\end{array}$ & $\begin{array}{l}\text { Zaporę stanowiły lasy augustowskie oraz rzeki Biebrza z szero- } \\
\text { kim pasem bagien i Narew, co utrudniało naturalne prowadzenie }\end{array}$ \\
\hline
\end{tabular}

${ }^{45}$ T. Kośmider, op. cit., s. 14-15. 


\begin{tabular}{|c|c|}
\hline Odcinek granicy & Po stronie Polski \\
\hline $\begin{array}{l}\text { Wschodnio- } \\
\text {-Pruski (cd.) }\end{array}$ & $\begin{array}{l}\text { operacji militarnych i stanowiło naturalną ochronę dla Podlasia. } \\
\text { Z tej strony jedynym przejściem był odcinek od Wizny do Su- } \\
\text { chowoli - co ograniczała twierdza Ossowiec. Niewielką zapo- } \\
\text { rę stanowiły także bagna myszynieckie. W przypadku Narwi } \\
\text { - nie stanowiła ona zapory dla ruchu wojsk. Również brakiem } \\
\text { naturalnych zapór charakteryzował się odcinek na zachód od } \\
\text { Orzycy aż po Drwęcę. Pierwsze zapory stanowiły twierdze } \\
\text { Modlin, Serock, Zegrze. Jedynie nieznaczna ilość przepraw } \\
\text { na Narwi i Biebrzy podnosiła walory obronne tego obszaru. }\end{array}$ \\
\hline $\begin{array}{l}\text { Rejon, Brodnicy, } \\
\text { Torunia, Grudziądza }\end{array}$ & $\begin{array}{l}\text { Linia obrony dolina Drwęcy i Osy z podwójnym łańcuchem } \\
\text { jezior. Tu główne punkty oporu: Brodnica, Jabłonowo i Gru- } \\
\text { dziądz. }\end{array}$ \\
\hline $\begin{array}{l}\text { Korytarz } \\
\text { Pomorski }\end{array}$ & $\begin{array}{l}\text { Bardzo trudny do obrony, nie posiadał granic naturalnych } \\
\text { i z dwóch stron graniczył z Niemcami, nie mógł być wykorzy- } \\
\text { stany militarnie. W części południowej, rubież obrony mog- } \\
\text { ły stanowić rzeki Brda i dopływ Noteci - Łobżonka; Bory } \\
\text { Tucholskie oraz pasma jezior w rejonie Tucholi, Więcborka, } \\
\text { Koronowa Mroczy i masyw Gór Dębowych pod Wyrzyskiem. } \\
\text { Skrzydła polskiej obrony ubezpieczały rzeki Wisła i Noteć. Osta- } \\
\text { teczną linię polskiej obrony stanowiły: Grudziądz-Bydgoszcz- } \\
\text { Nakło. }\end{array}$ \\
\hline Wielkopolska & $\begin{array}{l}\text { Teren równinny trudny do obrony. Przeszkody wodne stano- } \\
\text { wią jeziora na wschód i północ od Gniezna oraz na zachód od } \\
\text { południowego biegu Obry. Głównymi rzekami są Brda, Noteć } \\
\text { i Warta, ta ostatnia tworzy błota. Na północy przeszkodą natu- } \\
\text { ralną Wielkopolski jest rzeka Noteć. Strona południowa nie po- } \\
\text { siada naturalnych zapór. Kształt wielkopolskiego odcinka gra- } \\
\text { nicy umożliwia np. równoległe uderzenie na polskie skrzydła. }\end{array}$ \\
\hline Górny Śląsk & $\begin{array}{l}\text { Jedynymi terenami stanowiącymi naturalny element obrony } \\
\text { były płaskowyż ograniczony dolinami rzek Odry, Warty, Pilicy } \\
\text { i Wisły oraz kompleksy leśne. Rejon Dolnego Śląska dawał do- } \\
\text { godną pozycję do działań militarnych przeciwko Polsce. }\end{array}$ \\
\hline
\end{tabular}

Źró d to: oprac. własne na podstawie: T. KośmIDER, Planowanie wojenne w Polsce w latach 1921-1926, Toruń 2002, s. 16-18. 
W zasadzie pojawiały się dwie koncepcje przyjmowane jako kierunek ataku ze strony Niemiec: wariant I - zakładał główne uderzenie na linii Złotów-Bydgoszcz-Warszawa oraz wariant II - Górny Śląsk-Warszawa. Przyjmując pierwszy z nich jako bardziej prawdopodobny - należało podjąć prace związane z umocnieniem terenów międzyrzecza pomiędzy Wartą i Wisłą (koncepcja gen. Tadeusza Kutrzeby). Ze względów strategicznych, równie istotny był Górny Śląsk. Spodziewano się także niemieckiego ataku ze strony Pomorza i Prus Wschodnich, czego konsekwencją mogło być wycofanie wojsk polskich. Silnie umocniony Górny Śląsk umożliwiał utworzenie osi odwrotu polskiego na południowy wschód. Rzeczą oczywistą było, że w przypadku konfliktu wojennego Niemcy w pierwszej kolejności będą dążyły do zajęcia terenów II RP na północ od Bydgoszczy, co umożliwiłoby połączenie obszarów państwa niemieckiego. Sytuacja zaczęła się pogarszać po konferencji monachijskiej w 1938 r. oraz zajęciu przez Niemców Kraju Sudeckiego, utworzeniu Protektoratu Czech i Moraw i zbliżeniu Berlina z państwem słowackim. Plany te uległy zmianie w 1939 r. (o czym już wspomniano).

Przyjmując za niezbędne przygotowanie przemysłu polskiego na wypadek wojny, zdawano sobie sprawę z newralgiczności przemysłu na Górnym Śląsku - ani okręg warszawski, ani tworzony Centralny Okręg Przemysłowy nie były w stanie zastąpić pod względem gospodarczym ewentualnej utraty Górnego Śląska.

\section{Plany operacyjne „Wschód” i „Zachód”}

\section{W przypadku konfliktu ze Związkiem Radzieckim}

Przygotowywany plan operacyjny „Wschód” w swych założeniach opierał się na doświadczeniach wojny polsko-bolszewickiej z lat 1919-1920 (szczególnie koncepcja prowadzenia działań po liniach wewnętrznych ${ }^{46}$. Polecenie rozpoczęcia prac nad tym planem wydał gen. E. Śmigły-Rydz w listopadzie 1935 r. Plan miał charakter obronny z elementami zwrotów zaczepnych (osłabiających nieprzyjaciela), narzucenia terenu walki, rozdzielenia sił przeciwnika i zdecydowanych działań Obwodu Głównego Naczelnego Wodza. Koncepcja planu opierała się na rozwiązaniach opracowywanych w czasach J. Piłsudskiego, wynikach i studiach prowadzonych przez inspektorów armii oraz uzupełnieniach wprowadzonych przez E. Śmigłego-Rydza ${ }^{47}$. Prace nad planem wschodnim prowadził

${ }^{46}$ A. Grzywacz, Polski plan operacyjny „Wschód” a planowanie sowieckie w 1939 r., „Zeszyty Historyczne" 1996, nr 117.

${ }^{47}$ W. Stachiewicz, Wierności dochować żotnierskiej. Przygotowania wojenne w Polsce 1935-1939 oraz kampania 1939 w relacjach i rozważaniach szefa Sztabu Głównego i szefa Sztabu naczelnego Wodza, Warszawa 1998, s. 368-369. 
Oddział III SG pod kierownictwem płk. dypl. J. Jaklicza. Z Oddziałem tym współpracowały ściśle: Szefostwo Komunikacji Sztabu, Inspektorat Saperów (fortyfikacje), Szefostwo Łączności, jak również wszystkie oddziały Sztabu oraz oficerowie sztabów inspektorów armii, którzy wysuwali odpowiednie dezyderaty odnośnie do swych odcinków, które miały być uwzględnione w ogólnym planie (szczególnie autorstwa gen. K. Sosnkowskiego). Prace nad planem ukończono 4 lutego 1939 r. $^{48}$ Zakładano w nim wykorzystanie obszaru Polesia oraz istniejących fortyfikacji do obrony stałej ${ }^{49}$. Wojsko Polskie po rozpoznaniu sił przeciwnika miało wprowadzić do walki armie pierwszego rzutu operacyjnego, prowadząc początkowo działania siłami rozpoznawczymi (osłonowymi). Główna pozycja obronna przebiegać miała: rzeką Stryj na południu, dalej na wschód od Lwowa, wzdłuż Styru i Jasiołdy, Kanału Ogińskiego, Szczary i Niemna do granicy z Litwą. Zakładano w planie także utworzenie odwodów strategicznych na Podlasiu i w Małopolsce. W drugim etapie wojny przewidywano działania ofensywne z udziałem rzutu operacyjnego, sił osłonowych i odwodu Naczelnego Wodza - w zależności od rozwoju sytuacji militarnej ${ }^{50}$. Planowano również współdziałanie militarne z sojuszniczymi wojskami rumuńskimi, które powinny nacierać w kierunku na Płoskirów.

Do działań na wschodzie przewidziano Armie: „Wilno”, „Baranowicze”, „Wołyń” i „Podole”, Samodzielną Grupę Operacyjną „Polesie” oraz dwie Armie Rezerwowe (Odwodowe): „Lida” i „Lwów” ${ }^{\text {. Kl }}$ Kluczowe znaczenie odgrywało Polesie (vide schemat 1). Dla wzmocnienia obronnego charakteru tego odcinka, od $1936 \mathrm{r}$. zaczęto tworzyć system umocnień, który następnie miano rozbudowywać w kierunku północnym i południowym w oparciu o studia operacyjne dla poszczególnych armii ( $c f$. poniżej) $)^{52}$. Obronę granicy wschodniej oparto m.in. na linii poniemieckich umocnień $\mathrm{z}$ okresu I wojny światowej. Pracami prowadzonymi od przełomu lat dwudziestych i trzydziestych XX w. kierowali inspektorzy armii: gen. S. Dąb-Biernacki (odcinek wileński), gen. T. Piskor (odcinek nowogródzki), gen. K. Sosnkowski (poleski), gen. J. Romer i S. Burhardt-Bukacki (wołyńsko-podolski). Plan zakładał, że wojna prowadzona będzie wspólnie z Rumunią, przy

${ }^{48}$ Marszałek Edward Śmigły-Rydz zatwierdził plan „W” 26 lutego 1939 r. Vide: Przyczynki do genezy polskiego planu operacyjnego do kampanii 1939 r., „Bellona” 1952, nr 1, s. 12.

49 A. Aкsamitowsкi, Charakterystyka systemu umocnień stałych wschodniej granicy II Rzeczypospolitej, „Studia i Materiały do Historii Wojskowości” 1995, t. XXXVII, s. 290-291.

${ }^{50}$ Odwód Naczelnego Wodza miał znajdować się na pozycjach wyjściowych Siemiatycze-Brześć nad Bugiem, przez co mógł być użyty zarówno na odcinku ukraińskim, jak i białoruskim. Vide: M. LeCZyK, Polska i jej sq̨siedzi. Stosunki wojskowe 1921-1939, Białystok 1997, s. 91.

${ }^{51}$ C. Grzelak, H. Stańczyk, Kampania polska 1939 roku. Początek II wojny światowej, Warszawa 2005, s. 63-64.

${ }^{52}$ A. Aкsamitowski, op. cit., s. 291; L. WyszcZelski, W obliczu wojny. Wojsko Polskie 1935-1939, Warszawa 2008, s. 157. 
wsparciu materiałowym ze strony Francji i innych krajów zachodnich. Przewidywano atak sowiecki z kierunków: ukraińskiego - Kijów-Lwów-Kraków oraz białoruskiego - Mińsk-Baranowicze-Białystok-Warszawa i działania pomocnicze z Płoskirowa na Lwów ${ }^{53}$.

W początkowym okresie wojny, ciężar walki miały wziąć na siebie siły osłonowe. Dla poszczególnych związków operacyjnych rolę tę miały odgrywać: Armia „Wilno” - siły Grupy Operacyjnej „Postawy”; Armia „Baranowicze” - wydzielone oddziały 20 Dywizji Piechoty, Nowogrodzkiej Brygady Kawalerii oraz bataliony Korpusu Ochrony Pogranicza (KOP) „Kleck”, „Snów”, „Stołpce”; Samodzielna Grupa Operacyjna „Polesie” - 30 Dywizja Piechoty, bataliony KOP „Dawidogródek” i „Sienkiewicze”; Armii „Wołyń” - dwa pułki 13 Dywizji Piechoty, Wołyńska Brygada Kawalerii oraz bataliony KOP „Ostróg”, „Hoszcza” i „Bytyń”; Armia „Podole” - bataliony Brygady KOP „Podole”, oddziały 13 Dywizji Piechoty oraz jeden pułk Podolskiej Brygady Kawalerii. W drugim etapie wojny zamierzano przejść do działań zaczepnych: Armia „Lida” przy wsparciu odwodu Naczelnego Wodza miała zaatakować na kierunku białoruskim, zaś Armia „Lwów” - na ukraińskim, przy udziale odwodów Naczelnego Wodza odcinających siły przeciwnika na kierunku krakowskim ${ }^{54}$.

\section{Wykorzystanie środowiska naturalnego}

Armia „Wilno”. Określono w jej pasie działania dwa kierunki zagrożeń: korytarz postawski (wzdłuż osi Głębokie-Postawy-Wilno) i korytarz bracławski (wzdłuż osi Dryssa-Bracław-Święciany). W pierwszym przypadku wyznaczono trzy linie obrony z wykorzystaniem elementów naturalnych: linia jezior postawskich, Jezioro Narocz, Jezioro Szwakszta, lasy Łuntupy oraz Jezioro Świr i błota rzeki Stracza. Miały też powstać dwie linie osłonowe. Pierwsza miała przebiegać na północy od Jeziora Dryświaty przez Koziny, następnie wzdłuż linii kolejowej do Worpajewa i dalej łukiem do Jeziora Borotyn. Druga od Jeziora Narocz przez Postawy, Jezioro Bogiń, Jezioro Dryświaty w kierunku granicy państwa. Spodziewając się ataku z północnego-wschodu, od 1937 r. rozpoczęto prace nad odcinkiem zalewowym Potasznia oraz umocnieniami na odcinku Cwiecień-Usza w obszarze Puszczy Nalibockiej ${ }^{55}$. Samo miasto Wilno otrzymało w 1920 r. status obozu warownego. Najważniejsze zadania - w ramach Armii „Wilno” - postawiono przed Grupą Operacyjną „Postawy”, mającą nie dopuścić do dotarcia wojsk Armii Czerwonej do granicy z Litwą. Zamierzano wykorzystać do celów obronnych tereny od granicy z Łotwą do dolnej Dzisny. Był to obszar zalesiony,

\footnotetext{
53 A. GRZYWACZ, op. cit., s. 47.

54 L. WyszCZELSKI, op. cit., s. 159.

55 A. Aкsamitowski, op. cit., s. 295-299.
} 
trudnodostępny i podmokły, niemożliwy do działań pancerno-motorowych. Na kierunku południowym rozpościerała się tzw. Grzęda Święciańska, przez którą przebiegał „szlak bity” i linia kolejowa ze Święcian do Głębokiego. Teren ten był dogodny do działań ofensywnych. Z kolei na prawym odcinku położona była Puszcza Hołubicka, na której zapleczu znajdowała się wypływająca z jeziora Serwecz rzeka (o tej samej nazwie), węzeł drogowy Dobszyce oraz linia kolejowa do Mołodeczna i Lidy. Ważną rolę (o czym wspomniano) odgrywały dawne niemieckie umocnienia z okresu I wojny światowej ${ }^{56}$.

Armia „Baranowicze”. Przewidywano w jej pasie obrony trzy kierunki natarcia przeciwnika wzdłuż linii: Mińsk-Baranowicze, Mińsk-Mir-Nowogródek oraz wzdłuż tzw. Szosy słuckiej. Przyjęto rozwiązanie operacyjne polegające na obronie stałej, co miało polegać na maksymalizacji czynnika obronności terenu, przy wykorzystaniu istniejących fortyfikacji. Głównym zadaniem było zażegnanie niebezpieczeństwa odcięcia wojsk polskich na północy oraz zatrzymanie przeciwnika, co miało dać czas niezbędny dla koncentracji Odwodu Naczelnego Wodza. Oznaczało to konieczność obrony na kierunkach Grodno, Białystok i Brześć nad Bugiem, czemu sprzyjało ukształtowanie terenu i warunki naturalne. Zagrożenie widoczne było jedynie w części przylegającej do granicy. Dalej istniały wyniosłości u źródeł rzek Szczara i Serwecz, Wyżyna Nowogrodzka i Wysoczyzna Wołkowyska. Najważniejszym naturalnym elementem obronnym były cieki wodne, układające się południkowo - rzeki Szczara i Serweczy (rozlewiska i grzęzawiska) oraz tereny zalesione: Puszcza Nalibocka czy Puszcza Szczarska. Najniebezpieczniejszym szlakiem była tzw. Brama Horodyszcze, gdzie spodziewano się głównego uderzenia przeciwnika z kierunku Białorusi. Centralnym punktem były Baranowicze, skąd przebiegały ważne linie kolejowe: dwutorowa w kierunku Brześcia i jednotorowe w kierunku Lidy i Wołkowyska ${ }^{57}$.

Dla zwiększenia walorów obronnych terenu działania Armii „Baranowicze” podjęto na nim od $1928 \mathrm{r}$. szereg prac fortyfikacyjnych, dzieląc go na pięć odcinków: 1. odcinek „Niemen” - obszar Puszczy Nalibrockiej, teren zabezpieczano przez prace nawadniające, bez nowych schronów; 2. odcinek "Serwecz" - wzdłuż rzeki Serwecz - obiekty obronne na linii niemieckich okopów; 3. odcinek „Brama Horodyszcze" - na obszarze rzek Serwecz i Szczary (212 schronów bojowych); 4. odcinek „Centrum” - położony po obu stronach linii kolejowej Mińsk-Baranowicze, składał się z dwóch rejonów: Korczyn-Odachowicze (21 schronów bojowych) oraz Darewo-Łabuzy (26 schronów); 5. odcinek „Szosa Słucka” - wzdłuż biegu Szczary, miał osłaniać południową flankę węzła baranowickiego i zamykał trakt ze Słucka do Brześcia (43 schrony bojowe). Na Szczarze tworzono jazy

\footnotetext{
56 R. SzUBAŃsKi, op. cit., s. 105-108.

57 Ibidem, s. 117-120.
} 


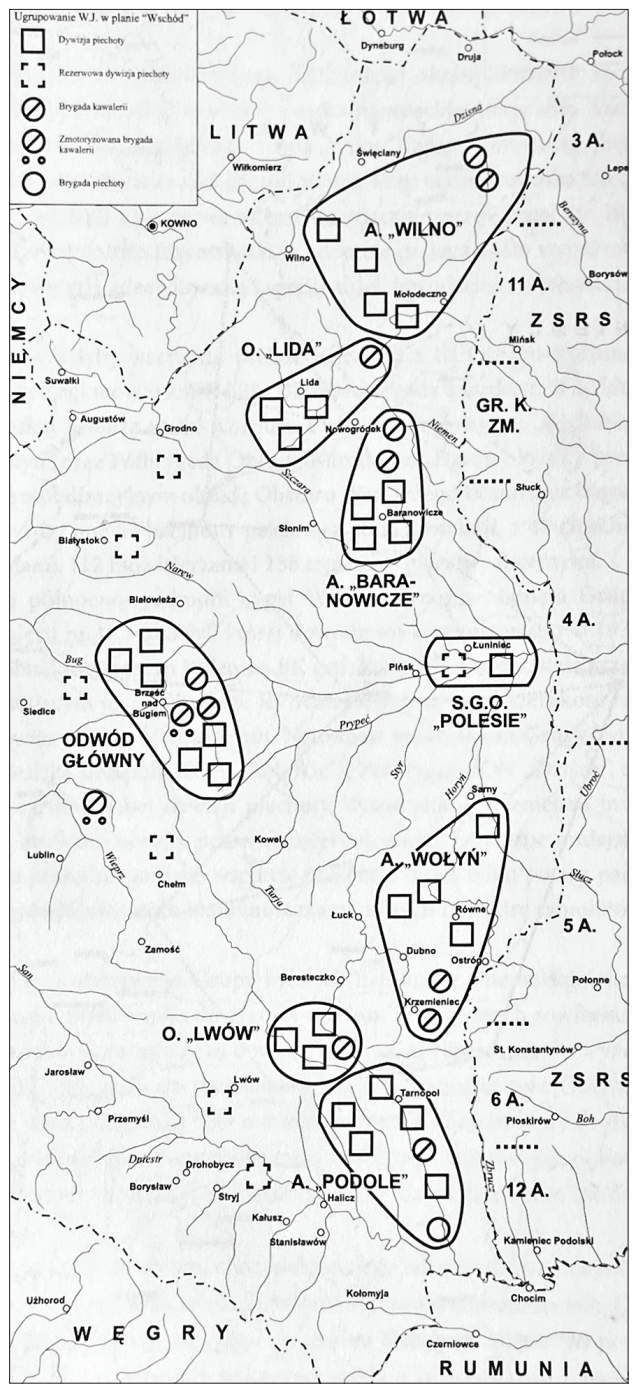

Schemat 1. Plan wojny obronnej z ZSRR „Wschód” - pozycja wyjściowa

Źród to: R. SzUBański, Plan operacyjny „Wschód”, Warszawa 2010, s. 103.

i zbiorniki wodne (miały powstać 3 zbiorniki i 12 stawów). Główny jaz piętrzący miał powstać na Kanale Ogińskiego - łączył Szczarę i Jezioro Wygonowskie ${ }^{58}$.

\section{Samodzielna Grupa Operacyjna} „Polesie”. Teren jej działania obejmował kompleks bagien, lasów i bezdroży. Był to wielki naturalny bastion obronny. Podstawą była oś Baranowicze-Łuniniec-Podstawy. W $1935 \mathrm{r}$. podjęto decyzję o pracach polegających na wzmocnieniu terenu poprzez budowę fortyfikacji i sztucznych zalewów. To właśnie tutaj jako podstawę przyjęto analizę terenu $\mathrm{z}$ perspektywy zmian pór roku. Całość obszaru została podzielona równoleżnikowo wzdłuż rzeki Prypeć (od rzeki Szczary do rzeki Horyń). Zakładano koncepcję „zakorkowania” szlaków komunikacyjnych. Wyodrębniono trzy odcinki: „Hancewicze”, „Łuniniec” i „Sarny”. Planowano oparcie obrony na obszarach: „Błota Olmiańskie” i „Błota Hryczyn”. Na odcinku „Hancewicze” i "tuniniec” nie wybudowano żadnych stałych fortyfikacji, za to na odcinku "Sarny” powstał system żelbetowych schronów ${ }^{59}$. O znaczeniu Polesia wspominał gen. J. Stachiewicz: „[...] siły własne na północ i południe Polesia miały opóźniać nieprzyjaciela, bastion Polesia miał być utrzymany obronnie, by utrwalić rozdział sił nieprzyjaciela i przesłonić masę manewrową (gros sił własnych) zebraną centralnie w rejonie Brześcia i przeznaczoną do uderzenia przeciwko siłom działającym na północ względnie na

\footnotetext{
58 Vide: A. Акsamitowski, op. cit., s. 299-303.

59 Ibidem, s. 304-309.
} 
południe od Polesia. Uderzenie jej miałoby doprowadzić do decydującej bitwy z głównymi siłami nieprzyjaciela, która by załamała jego ofensywę" ${ }^{30}$. W przypadku pojawienia się na odcinku centralnym przeważających sił wroga, należało je zatrzymać na przedpolach Pińska, Kanału Ogińskiego, Jasiołdy i Styru ${ }^{61}$.

Armia „Wołyń”. Teren działania tej armii miał otwarty charakter. Znajdowały się tam ważne węzły komunikacyjne: Łuck, Równe i Dubno. Dla celów obronnych starano się wykorzystać system dopływów rzek: Prypeć, Horyń, Ikwa i Styr. Ważnym elementem obrony była osłona linii kolejowej: Brody-Dubno-Zdołbunów, szczególnie most na rzece Horyń (w Aleksandrowie). Zamierzano również ufortyfikować północne skrzydło obrony na odcinku Dubno-Krzemieniec, na odcinku rzeki Ikwy. W planach było zalesienie maskujące oraz wzmocnienie zalewów. Nie planowano budowy dużych obiektów fortecznych w innych częściach obszaru działania armii. Budowano łańcuch schronów bojowych ${ }^{62}$.

Armia „Podole”. Działania ograniczały się tu do rzek: Zbrucz, Dniestr, Czeremosz i granicy państwa (z Rumunią). Głównym zadaniem było utrzymanie linii kolejowej Lwów-Śniatyń (połączenie z Rumunią) oraz bazy kolejowej we Lwowie. Zakładano możliwość wykorzystania rzek: Gniezny, Seretu i Strypy a także wzmocnienia przyczółków mostowych na Dniestrze. Ważnym elementem działań była koncepcja wzmocnienia węzła „Tarnopol” i linii kolejowej: Lwów-PotutoryTarnopol. W tym celu stworzono cztery rejony działań: „Zbaraż” (wykorzystanie stawów i zabagnionych łąk nad rzeką Gniezną); rejon „Czerniowiec” (głównie przejście przez rzekę Gnieznę - zamknięty na przeszkodzie wodnej); rejon „rzeki Gniezny” (oparty na schronach bojowych) oraz rejon "Słupca-Borki Wielkie” (głównie umocnienia stałe rozmieszczone na zachodnim brzegu rzeki Słupca). Ponadto, zaplanowano utworzenie rejonu obronnego "Mikulińce” - powiązanego z przedmościem tarnopolskim. Centralnym elementem były umocnienia na rzece Strudze. Z kolei na odcinku „Podhajce-Monasterzyska” przewidywano osłonę 8 przepraw na rzece Koropca. Umocnienia (system polowy) miały powstać na linii rzeki Złota Lipa (odcinek Bereżany-Rudnik-Podhajce). Wzmocnienie przedmościa na Dniestrze planowano dokonać w m. Niżnów, Jezupol i Halicz (w tym przypadku zakładano budowę osłony mostu kolejowego na rzece Gniła Lipa pod Siemikowcami). Planowano powstanie przeszkód zalewowych na odcinku rzek: Seret, Strypa i Koropiec, a w m. Zołożce miał powstać jaz, grobla i zbiornik retencyjny; w m. Wertełka - jaz, grobla (jako zalew stały); w Pleszkowicach

\footnotetext{
60 W. STACHIEWICZ, op. cit., s. 370.

61 R. SzUBAŃski, op. cit., s. 136.

${ }^{62}$ Polskie Siły Zbrojne..., s. 309-312; R. Szubański, op. cit., s. 139-140.
} 
i Zagrobku - jazy i groble; w m. Iwaczów Górny - jaz i grobla tworzące zbiornik retencyjny, a w Berezowcu - jaz przelewowy i grobla ${ }^{63}$.

\section{W przypadku konfliktu z Niemcami}

Polskie plany wojenne powstałe po I wojnie światowej zakładały zaczepno-obronny charakter prowadzenia działań militarnych przeciwko Niemcom. W końcu czerwca 1920 r. Naczelne Dowództwo WP przystąpiło do przygotowania planu obrony Polski przed agresją niemiecką, który miał obowiązywać w latach 1922-1923. W każdym z trzech opracowanych wariantów, autor planu - gen. Paul Henrys - zakładał skrócenie frontu poprzez opanowanie Prus Wschodnich, ewentualnie Dolnego i Górnego Śląska oraz Pomorza, a także likwidację niemieckich baz na tych obszarach ${ }^{64}$. Przewidywano także, że działania militarne będą powiązane $\mathrm{z}$ działaniami zachodnich sojuszników (głównie Francja), w końcu zaś wykonanie generalnej ofensywy na Berlin ${ }^{65}$.

Pierwsze studium wojny z Niemcami powstało w sztabie Inspektoratu Armii w Krakowie wiosną $1921 \mathrm{r}$. Jej autorem był płk Jan Thullie, który przedstawił trzy warianty konfliktu: 1) samodzielnej wojny; 2) w sojuszu z Francją; 3) w koalicji z Francją i Czechosłowacją ${ }^{66}$. Pierwszy z wariantów przewidywał obronny charakter wojny, co oznaczało jej narzucenie przez nieprzyjaciela. Taki stosunek do samodzielnego wariantu wojny przetrwał do 1939 r. Rozmowy polsko-francuskie prowadzone przez gen. Władysława Sikorskiego, gen. Stanisława Hallera i wreszcie marszałka J. Piłsudskiego, miały po 1921 r. na celu sprecyzowanie warunków zastosowania w praktyce postanowień polsko-francuskiej konwencji wojskowej z 1921 r. Polska koncepcja operacyjna oparta była na zasadzie działań obronno-zaczepnych. Obejmowała ona plany ofensywy w Prusach Wschodnich oraz zaczepną obronę w Wielkopolsce, Pomorzu (utrzymanie dostępu do morza) w Zagłębiu Dąbrowskim i na Górnym Śląsku ${ }^{67}$.

\footnotetext{
${ }^{63}$ A. Aкsamitowski, op. cit., s. 312-317.

${ }^{64}$ Polskie Sity Zbrojne..., s. 112-113.

${ }^{65}$ Pierwsza faza miała polegać na równoczesnym ataku na Prusy Wschodnie, zajęciu Wrocławia po Odrę i Górnego Śląska. Druga faza: ofensywa generalna ku dolnej Odrze oraz likwidacja występu śląskiego. Ostatnia faza to generalna ofensywa na Prusy Wschodnie i Górny Śląsk. Vide: T. JurgA, 1939. Obrona Polski i Europy, Warszawa 2014, s. 183; C. Filus, Koncepcje i plany obrony granicy polsko-niemieckiej oraz ich realizacja w latach 1918-1939, [w:] Szkice z dziejów wojskowych Polski 1918-1939, red. B. Miśkiewicz, Poznań 1979, s. 31-32.

${ }^{66}$ M. Cieplewicz, Studium wojny z Niemcami z 1921 roku, „Studia i Materiały do Historii Wojskowości" 1981, t. XXIII, s. 333-365.

${ }^{67}$ M. LeczyK, op. cit., s. 35; Vide: H. BuŁHaK, Polska-Francja. Z dziejów sojuszu 1922-1939, cz. I (1922-1932), Warszawa 1993.
} 
Kiedy w maju 1923 r. przybył do Polski marszałek Ferdynand Foch, podjęto rozmowy dotyczące ewentualnej wspólnej ofensywy polsko-francuskiej przeciwko Niemcom. Strona francuska zakładała wspólne uderzenie na Berlin ${ }^{68}$. Plan ten, znany jako „plan Focha”, nigdy nie został opracowany w formie sztabowego planu operacyjnego, choć jego postanowienia obowiązywały prawie do połowy lat trzydziestych ${ }^{69}$. W trakcie tej dekady, po przyjęciu koncepcji wojny obronnej z Niemcami, nastąpił wzrost zagrożeń na odcinku tzw. Korytarza Pomorskiego (szerokości $25-100 \mathrm{~km}^{70}$ ), czego następstwem mogło być odcięciem Polski od morza. Jeszcze większe zagrożenie stanowiła możliwość niemieckiego ataku na Polskę z dwóch stron: z Prus Wschodnich i Pomorza oraz ze Śląska, który pod względem operacyjnym był wyraźnie niekorzystnie usytuowany ${ }^{71}$. Do początku lat trzydziestych, polskie plany militarne były zdecydowanie ofensywne w stosunku do Niemiec. Musimy jednak zauważyć, że uwzględniały współdziałanie militarne z Francją. Poza działaniami „Laboratorium”, prace na kierunku przeciwniemieckim (studium operacyjne) zlecono inspektorom armii w GISZ: Juliuszowi Rómmlowi i Leonowi Berbeckiemu oraz dwóm generałom skierowanym do pracy w GISZ: Tadeuszowi Kutrzebie i Władysławowi Bortnowskiemu. W 1936 r. przygotowywano (gen. T. Kutrzeba) Studium Niemcy, w którym porównywano możliwości militarne Niemiec i Polski. W opracowaniu określono zdolność militarną państwa niemieckiego do wojny przeciwko koalicji polsko-francuskiej na rok $1940^{72}$. Ustalono wstępny plan wojny na zachodzie, którego strona operacyjna miała być przygotowana po stworzeniu Planu „Wschód”73.

Przed przyjazdem do Polski gen. Maurice’a Gamelena (sierpień 1936 r.) przygotowano w GISZ plan wojny, który miał roboczy charakter. Przewidywano dwa kierunki działań operacyjnych. Główne uderzenie ze strony niemieckiej armii miało wyjść z Pomorza Zachodniego na Łódź-Skierniewice, wspomagane przez uderzenie z Prus Wschodnich (w kierunku Toruń-Włocławek i dalej Warszawa) oraz działanie pomocnicze z obszaru Dolnego Śląska w stronę Górnego Śląska. Polacy mieli wystawić pięć armii. Na głównym kierunku uderzenia Armie „Poznań” i „Pomorze” miały zneutralizować uderzenie z Pomorza Zachodniego,

68 Szerzej J. CiaŁowicz, op. cit., s. 89-97.

${ }^{69}$ M. Porwit, Komentarze do historii polskich działań obronnych w 1939 r., Warszawa 1969, s. $43-44$.

70 R. Umiastowski, Terytorium Polski..., s. 98.

71 T. Kutrzeba, Studium nad możliwościami wojennymi Niemiec i Polski, „Wojskowy Przegląd Historyczny” 1964, nr 3, s. 271.

72 E. KozŁowski, Studium gen. Tadeusza Kutrzeby nad możliwościami wojennymi Niemiec i Polski, „Wojskowy Przegląd Historyczny” 1964, nr 3, s. 41 i 271.

73 W. IwANOwski, Wysiłek zbrojny narodu polskiego w czasie II wojny światowej, t. I, Kampania wrześniowa 1939, Warszawa 1961, s. 99-103; M. Porwit, op. cit., s. 46-47; Polskie Sity Zbrojne..., s. 122-127. 
Armia „Warszawa” działająca na Mazowszu i Podlasiu - miała zatrzymać uderzenie z Prus Wschodnich, Armia "Częstochowa-Łódź” - zneutralizować natarcie z Dolnego Śląska, zaś Armia Odwodowa (rejon Kutna) miała reagować w zależności od zagrożenia. Po zatrzymaniu niemieckiego uderzenia, planowano atak na Prusy Wschodnie ${ }^{74}$.

Na przełomie lat 1937 i 1938 powstało Studium planu strategicznego Polski przeciw Niemcom ${ }^{75}$. Opracowanie przygotowano pod kierunkiem gen. T. Kutrzeby, choć jego autorstwo przypisywane jest także ppłk. Stefanowi Mossorowi. W drugiej części Studium, zatytułowanej Elementy decyzji strategicznej planu strategicznego i operacji wstępnej - mając świadomość braku możliwości prowadzenia samodzielnej wojny z Niemcami, twórcy koncepcji zakładali, iż najważniejszym z problemów będzie wytrzymanie uderzenia armii niemieckiej i utrzymanie jak najlepszych pozycji obronnych (obrona strategiczna) do czasu otrzymania francuskiego wsparcia. W ramach Studium nie przewidywano obrony całego kraju, lecz tzw. "tułowia strategicznego kraju” - koncepcja gen. T. Kutrzeby. Obszar ten miały wyznaczać: rzeka San, północny stok Karpat i granica Śląska, Częstochowa, Wieluń, Ostrów Wielkopolski, Gniezno, Inowrocław, Włocławek, Sierpc, Modlin, Warszawa oraz Środkowa Wisła. Zakładano, że nasz punkt ciężkości strategicznej potencjału wojskowego leży pomiędzy: Wartą-Notecią-Wisłą i pograniczem śląskim ${ }^{76}$.

Obrona strategiczna miała mieć miejsce do chwili osiągnięcia pełnej mobilizacji wojennej. Plan dotyczył wojny jednofrontowej, o obronnym charakterze, toczonej z pomocą sojuszników, szczególnie alianta francuskiego ${ }^{77}$. Ważną rolę odegrać miał podział obszaru walk, poprzez niedopuszczenie do połączenia sił niemieckich na północy i południu naszych zachodnich granic. $Z$ tego powodu zamierzano jak najdłużej bronić tzw. „Występu Poznańskiego"78. Teren nazywany „tułowiem strategicznym” miał stać się obszarem, gdzie miało dojść do koncentracji wojsk operacyjnych i mobilizacji rezerw strategicznych. W przypadku korzystnego rozwoju sytuacji wojennej - to stąd miała być kierowana ofensywa w kierunku Pomorza Wschodniego i Zachodniego oraz na Wrocław i Berlin. Nastąpiła więc ewidentna zmiana koncepcji wojny przeciwko Niemcom. Wojna miała mieć charakter obronny, gdyż Polska nie była zdolna do samodzielnej ofensywy przeciwko Niemcom.

${ }^{74}$ L. Wyszczelski, op. cit., s. 153.

75 Vide: „Studium planu strategicznego przeciwko Niemcom” Kutrzeby i Mossora, wstęp P. STAWECKI, oprac. M. JABŁońsKi, P. STAWECKI, Warszawa 1987.

76 Ibidem, s. 105.

77 Ibidem, s. 76-77.

78 Ibidem, s. 116. 


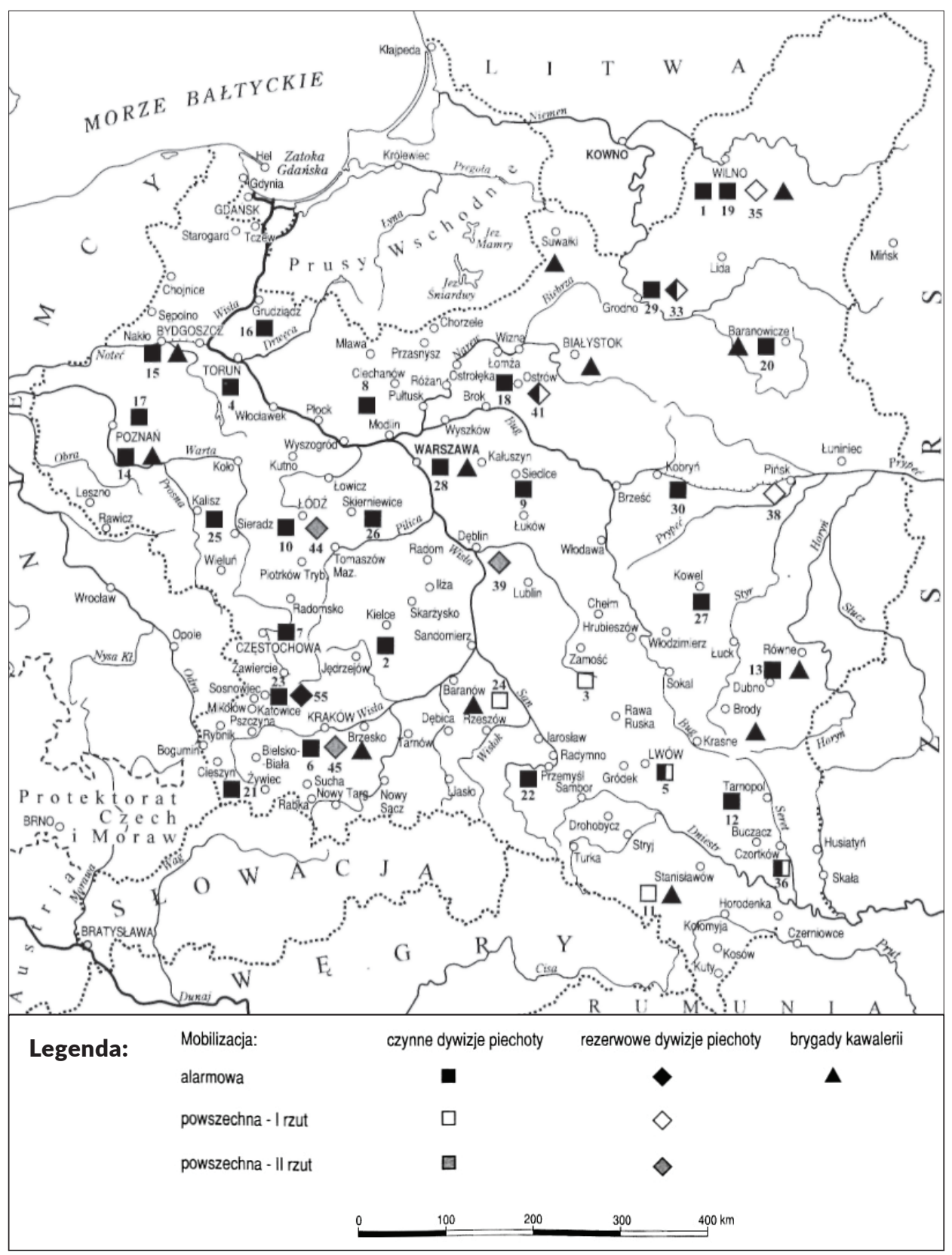

Schemat 2. Plan obronny - rozwinięcie WP w dniu 31 sierpnia 1939 r.

Źr ó dło: W. StACHIEWIcz, Wierności dochować żołnierskiej. Przygotowania wojenne w Polsce 1935-1939 oraz kampania 1939 w relacjach i rozważaniach szefa Sztabu Głównego i szefa Sztabu naczelnego Wodza, Warszawa 1998, s. 389. 
W przypadku zachodniej granicy państwa GISZ wyznaczył zadania dla inspektorów armii - mieli przygotować terenowe prace studialne odnośnie całego frontu zachodniego ${ }^{79}$. Również w SG niezwłocznie przystąpiono do prac nad szczegółowym Studium Niemcy. W wypadku uderzenia z tej strony, przewidywano działania obronno-ofensywne, w ścisłym współdziałaniu z armią francuską. Cel działania wojsk polskich miał opierać się na koncepcji utrzymania jak największego obszaru nadgranicznego, a następnie po rozpoczęciu ofensywy przez Francję - uderzenia i zajęcia Prus Wschodnich. W tej sytuacji armia polska uzyskiwała bowiem możliwość przejścia do działań ofensywnych w kierunku zachodnim i nawiązania współdziałania z Francją.

Tworzenie Planu „Zachód” rozpoczęto w marcu 1939 r. Cele i wyjściowe założenia tego planu marszałek E. Śmigły-Rydz przekazał 23 marca dowódcom stworzonych grup operacyjnych i armii: Samodzielnej Grupy Operacyjnej „Narew”, Armii „Modlin”, „Pomorze”, „Poznań”, „Łódź”, „Kraków” oraz Armii Odwodowej „Prusy”, jak również dowódcom lotnictwa i Marynarki Wojennej (vide schemat 2). Uważano, że umocnienia stałe - przy ówczesnym poziomie przygotowania broni pancernej i lotnictwa - nie będą w stanie zatrzymać przeciwnika. Stawiano tezę, że wojna przeciwko Niemcom w fazie początkowej powinna być wojną manewrową o charakterze obronnym. Ofensywa była realna po przystąpieniu do wojny sojuszników (Francja i Wielka Brytania) - druga faza wojny.

Główne pozycje oporu miały przebiegać na północy - od Puszczy Augustowskiej wzdłuż Biebrzy, Narwi oraz Wisły do ujścia Brdy, następnie w kierunku południowym, od Chojny przez Bydgoszcz, Żnin, wzdłuż górnej Noteci i Warty, przez umocnienia śląskie w kierunku Karpat. W związku z zagrożeniem od strony Słowacji - została utworzona w lipcu 1939 r. Armia „Karpaty” Planowano stoczenie generalnej bitwy w łuku Wisły z udziałem Armii: „Łódź”, „Prusy”, „Poznań” i Odwodu „Kutno”81. W pracach nad Planem „Zachód” utworzono trzy grupy planów: cywilnych, kwatermistrzowskich oraz operacyjnych. Rozważając wariant całkowitego zniszczenia zdolności obronnych Polski, zakładano uderzenie Niemców w dwóch zgrupowaniach, główne: w rejonie Wrocław-Opole, nacierające na Warszawę przez Łódź-Piotrków Trybunalski oraz drugie z Pomorza Zachodniego z zamiarem połączenia z Prusami Wschodnimi i natarcia przez Bydgoszcz-Kutno na Warszawę ${ }^{82}$. Z powodu znacznej przewagi strony niemieckiej (70-80 dywizji oraz 3500 samolotów), zakładano prowadzenie działań defensywnych, dających czas na przygotowanie wojsk sojuszniczych aliantów zachodnich. Pierwsze uderzenie przeciwnika miały odpierać związki

\footnotetext{
79 E. KozŁowski, op. cit., s. 249-251.

80 W. Stachiewicz, Pisma..., s. 255.

81 C. Grzelak, H. Stańczy , op. cit., s. 65.

${ }^{82}$ Polskie Sity Zbrojne..., s. 273.
} 
taktyczne armii pierwszego rzutu, zorganizowane w trybie alarmowym. Plan obejmował jedynie pierwszą fazę rozwinięcia wojsk na pozycjach obronnych oraz bitwy na pozycji głównej, nie zawierał wytycznych dla marynarki wojennej i lotnictwa. Przyjrzyjmy się sytuacji na poszczególnych odcinkach frontu przeciwniemieckiego:

Armia „Poznań”. Miała osłaniać Wielkopolskę przed uderzeniem niemieckim z kierunku Frankfurt-Poznań i utrzymać się jak najdłużej na linii przedpola Warty. Ostateczna pozycja obronna miała przebiegać na linii: przedmoście Bydgoszcz - jezioro Żnin - jezioro Gopło - kanał Gopło - Warta - rzeka Warta, z wysunięciem się w rejon Konin-Turek. Obszar Niziny Wielkopolskiej stanowił odcinek najbardziej wysunięty na zachód, lecz pozbawiony był naturalnych przeszkód. Na odcinku środkowym granicy - wzdłuż Warty i Odry - znajdował się niemiecki rejon ufortyfikowany Kostrzyna i Słubic ${ }^{83}$. W 1938 r. został sporządzony plan umocnień (gen. T. Kutrzeba), zakładający modernizacje starych niemieckich twierdz: Poznań i Grudziądz. Umocnieniu miał ulec także naturalny obszar Jezior Wągrowieckich. Przekopano również przesmyki pomiędzy Jeziorami Inowrocławskimi i przygotowano je do obrony ${ }^{84}$.

Armia „Pomorze”. Pozycja ostateczna obrony: Wisła z przedmościem Bydgoszcz-Toruń. Zadania koncentrowano na czterech odcinkach: północnym - granica z Wolnym Miastem Gdańskiem i dalej w kierunku zachodnim wzdłuż linii: od Tczewa, przez Skarszewy do Kościerzyny; południowym - wzdłuż linii: Łobżenica, Nakło nad Notecią, Władysławowo, Broniewo do Modliborzyc; wschodnim - wzdłuż linii: Rybno, Górzno, Gójsk do Dobrzynia nad Wisłą; zachodnim - granica z Rzeszą Niemiecką.

Zakładano konieczność zniszczeń komunikacyjnych, które ograniczyłyby szybkie połączenie Prus Wschodnich z Niemcami na kierunku KościerzynaTczew i Chojnice-Tczew (w tym mostu w Tczewie). Umocniono przyczółek bydgoski - zbudowano tu 35 schronów betonowych i 12 drewnianych. Umocniono także przyczółek toruński oraz przedpole linii Grudziądz-Brodnica, poprzez wykorzystanie starych fortyfikacji niemieckich. Zamknięto również przesmyki pomiędzy jeziorami Koronowskimi oraz podjęto prace fortyfikacyjne na tzw. linii „Grzmota” - linia rzek Kamionna i Brda po Jezioro Łąckie. Umocniono także rejon Więcborka oraz pozycje Chojnice-Jezioro Charzykowskie, zabezpieczono umocnienia mostów na Noteci pod Nakłem i na Wiśle we Włocławku, koło Fordonu. Przygotowano również most łyżwowy (z możliwością szybkiego montażu - między Toruniem a Chełmnem) ${ }^{85}$. Naturalny kształt terenu miał wykorzystać także

\footnotetext{
${ }^{83}$ R. Umiastowski, Geografia wojenna..., s. 58-60.

${ }^{84}$ Polskie Siły Zbrojne..., s. 126. J. Jaklicz, op. cit., s. 72.

85 Polskie Siły Zbrojne..., s. 381-382.
} 
układ fortyfikacyjny w rejonie Grudziądza, wzdłuż rzeki Osa od miejscowości Kłódka do ujścia do Wisły. Spiętrzono Osę i Górną Drwęcę, przekopano przesmyki między jeziorami Koronowskimi osłaniając przedmieścia Bydgoszczy ${ }^{86}$.

$\mathrm{Na}$ odcinku nadmorskim zamknięto stałymi fortyfikacjami półwysep Hel i utworzono Obronę Wybrzeża ${ }^{87}$. Za najważniejsze jej zadanie uznano utrudnienie komunikacji III Rzeszy z Prusami Wschodnimi, obronę portów Gdynia i Hel (siedziba Dowództwa), uniemożliwienie wrogowi zajęcia Kępy Oksywskiej oraz utrudnienie mu dojścia na przedpole polskich pozycji. Poważnym problemem okazała się koncepcja powstania tzw. Korpusu Interwencyjnego, który miał m.in. zająć Wolne Miasto Gdańsk w przypadku niemieckiego ataku oraz reagować w przypadku zagrożenia granic państwa. W dniu 31 sierpnia 1939 r. Kwatera Główna Naczelnego Wodza podjęła decyzję o wycofaniu się z koncepcji użycia Korpusu: elementy pozadywizyjne korpusu i 13 Dywizja Piechoty otrzymały rozkaz załadowania i odejścia do dyspozycji Naczelnego Dowództwa, zaś 27 Dywizję Piechoty oddano do dyspozycji dowódcy armii.

Armia Kraków. Zakładano trwałość granicy południowej opartej o Karpaty. Pojawiła się koncepcja tzw. „zawiasu” na linii północ-południe w kierunku zachodnim lub wschodnim. Od zachodu Górny Śląsk miał być chroniony linią fortyfikacji od Bobrownik do Kochłowic $(22 \mathrm{~km})$. W 1939 r. Karpaty utraciły jednak swoje strategiczne znaczenie. Rdzeniem polskich pozycji obronnych miał być obszar warowny „Katowice”. Na południu prace miały dotrzeć do rzeki Gostynki oraz rejonu Mikołowa. W rejonie Kobiór miał powstać samodzielny węzeł obronny. Rozbudowano ośrodki oporu w rejonie Węgierskiej Górki i Torbielowa oraz podjęto prace nad stworzeniem ośrodków oporu: Bystra, Jordanów, Skomielna, Raba Niższa. Wykorzystano na skrzydłach fortyfikacji tereny zalewowe na rzekach Brynicy i Gostynie ${ }^{88}$. Wybudowano tam wielki zbiornik wodny, którego działanie rozszerzono przez dodatkowe zamknięcie śluz ${ }^{89}$. Dolny Śląsk miał charakter klina, który wbijał się pomiędzy Polskę a Czechosłowację, a w 1939 r. po zajęciu Kraju Sudeckiego oraz utworzeniu Protektoratu Czech i Moraw - w niebezpieczny sposób zagrażał terenowi centralnej Polski i Górnemu Śląskowi (300 km granica). Z tego rejonu było bliżej do Warszawy niż z obszaru Pomorza Zachodniego. Pogranicze polsko-niemieckie na Śląsku pod względem ukształtowania terenu i braku większych przeszkód naturalnych sprzyjało natarciu przeciwnika ${ }^{90}$.

\footnotetext{
${ }^{86}$ J. JAKLICZ, op. cit., s. 72.

87 W. STACHIEWICZ, op. cit., s. 158

88 Polskie Siły Zbrojne..., s. 394-395. Cf. W. StAchiewicz, op. cit., s. 157.

89 Ibidem, s. 158.

90 P. Stawecki, Polska polityka wojskowa 1921-1926, Warszawa 1981, s. 20.
} 
Samodzielna Grupa Operacyjna „Narew”. Podstawowym zadaniem tej Grupy Operacyjnej była ochrona linii kolejowej Grodno-Białystok-Warszawa oraz zatrzymanie przeciwnika na linii Narew-Bug-Wisła, z wykorzystaniem kluczowych odcinków na Narwi (Wizna) na Biebrzy (Lipsk-Sztabin). Duże znaczenie w kształtowaniu linii obrony miała odgrywać Puszcza Augustowska ${ }^{91}$. W planach była budowa kilku tam oraz grobli w dorzeczu Narwi i Biebrzy. Konkretne plany fortyfikacji dotyczyły np. twierdzy w Osowcu i starych fortyfikacji w Łomży. Powstawały umocnienia na kierunku prawdopodobnych działań nieprzyjaciela (Ostrołęka, Nowogródek, Łomża, Wizna, Ossowiec, Augustów, Puszcza Augustowska - system blokhauzów i przeszkód), gdzie budowano schrony oraz umocnienia polowe: rowy strzeleckie i łącznikowe, druty kolczaste, zapory przeciwpancerne ${ }^{92}$.

Armia „Modlin”. Jej głównym zadaniem była osłona kraju od strony Prus Wschodnich na kierunku warszawskim i płockim. Duże znaczenie miało mieć zatrzymanie nieprzyjaciela na linii Wisła-Narew, utrzymanie wyjścia na północny brzeg Wisły w Modlinie i Narwi w Pułtusku oraz osłona na kierunkach uderzenia nieprzyjaciela $\mathrm{w}$ kierunku Warszawy. Istotnym elementem działań było utrzymania mostów na Wiśle, Bugu i Narwi. Na odcinku od Rożana do Płocka istniało 10 mostów (drogowe i kolejowe). Umocnieniu poddano czołową linię obrony w rejonie Mławy oraz na przyczółkach mostowych na Wiśle, Bugu i Narwi ${ }^{93}$. Dla stworzenia dogodnych warunków obrony spiętrzono Górny Orzyc i Górną Działdówkę ${ }^{94}$.

Armia Łódź. Główna pozycja oporu tego związku operacyjnego została wyznaczona wzdłuż Warty i jej prawego dopływu Widawki. Był to jedyny obszar, na którym dzięki wielkim torfowiskom, można było zbudować naturalne przeszkody terenowe ${ }^{95}$. Pozycja ta znajdowała się w odległości około $90 \mathrm{~km}$ od granicy - na jej skrzydłach i około $60 \mathrm{~km}$ - w pozycji obronnej. Dowódca armii został też poinformowany, że na jego prawym skrzydle Armia „Poznań” w razie konieczności cofania się będzie opóźniać przeciwnika na kierunku Głogów-Koło, zaś bronić się będzie nad Wartą - w oparciu o tzw. Przedmoście Kolskie.

Armia Karpaty. W związku ze zmianami na granicy południowej II RP utworzono Armię „Karpaty”, co radykalnie przedłużyło polskie lewe skrzydło aż po granicę z Węgrami, co miało zapewnić osłonę od strony Słowacji i (co brano

\footnotetext{
${ }^{91}$ Polskie Sity Zbrojne..., s. 283.

${ }^{92}$ Ibidem, s. 366-367. Cf. W. STACHIEWICZ, op. cit., s. 157.

${ }_{93}$ Polskie Sity Zbrojne..., s. 371-372.

${ }^{94}$ J. JAKLICZ, op. cit., s. 72.

95 W. STAChiewicz, op. cit., s. 158-159.
} 
także pod uwagę) Węgier, ale głównie obronić Centralny Okręg Przemysłowy. Dzieliła się na dwa odcinki „Węgry” i „Słowacja”.

Armia „Prusy”. Stanowiła ona główny odwód Naczelnego Wodza i miała być ześrodkowana w rejonie Radomia-Kielc i Tomaszowa Mazowieckiego.

Dodatkowo, dowódcy wszystkich armii byli zobowiązani wykonać na swoich odcinkach (według zatwierdzonych przez GISZ planów) umocnienia polowe. Na początku prace te prowadzono na terenach należących do wojska i na terenach niezasiewowych, a następnie na całym obszarze państwa. Problemem było jednak utrzymanie na terenach zalewowych poziomu wód i zalanych bagien. Suche lato spowodowało wyschnięcie zalanych obszarów, a poziom wód był na tyle niski, że nie stanowił poważniejszej przeszkody. Przewidywano również masowe zniszczenia komunikacyjne na obszarze pomiędzy granicą państwa a pozycjami obronnymi armii. Budowano w mostach komory minowe oraz tworzono zawały leśne. Program zniszczeń najszerzej przygotowano na Pomorzu, dotyczył on głównie linii komunikacyjnych z zachodu na wschód, co miało utrudnić szybkie połączenie wojsk niemieckich uderzających z Pomorza z siłami skoncentrowanymi w Prusach Wschodnich. Przygotowano do wysadzenia mosty, np. na Wiśle w Tczewie, czy tunele kolejowe, np. tunel Jabłonowski na granicy ze Słowacją. Budowano także nowe mosty (drogowe) mające umożliwić ewentualne wycofanie się polskich oddziałów za Wisłę, np. w Górze Kalwarii, pod Świdrem, Maciejowicami, Solcem, Puławami i Annopolem, Baranowem, Mogiłą oraz na Pilicy ${ }^{96}$.

\section{Podsumowanie}

Koncepcja wykorzystania środowiska naturalnego w prowadzeniu działań militarnych nie jest zjawiskiem nowym, istnieje od pojawienia się pierwszych konfliktów między zorganizowanymi, wrogimi sobie grupami ludzi, plemionami czy państwami. Środowisko przyrodnicze jest zmienne i uzależnione od wielu czynników, jak temperatura, poziom wód, przeszkody naturalne: rzeki, jeziora, morza, góry (i ich wysokości), jary, wąwozy, rodzaje gleb, czy poziom zalesienia. Prezentowana $\mathrm{w}$ artykule analiza oparta została na założeniach dwóch planów wojennych („Wschód” i „Zachód”), które powstały w Polsce w ostatnim okresie poprzedzającym wybuch II wojny światowej. Ze względu na poziom zagrożenia bezpieczeństwa państwa na poszczególnych odcinkach działań operacyjnych i taktycznych, starano się zwiększyć możliwość wykorzystania środowiska przyrodniczego, poprzez budowę sztucznych obiektów - powstałych dzięki ludzkiej działalności. Dotyczy to zarówno budowy fortyfikacji i umocnień polowych, jak

\footnotetext{
${ }^{96}$ Ibidem, s. 159-160.
} 
i tworzenia terenów zalewowych, spiętrzania wód, budowy zbiorników wodnych, mostów i wszelkich możliwych przepraw przez tereny podmokłe czy rzeki. Równocześnie przygotowano plany zniszczeń, które dotyczyły głównie obiektów komunikacyjnych, mostów, tuneli, dróg kolejowych oraz szos czy dróg bitych. Działania takie wynikały $\mathrm{z}$ dwóch planów koncepcyjnych, określonych jako przewidywane działania w przypadku konfliktu z III Rzeszą lub Związkiem Radzieckim. Co prawda, Plan „Zachód” był jedynie założeniem dla początkowego okresu przyszłej wojny, toteż wielce wymowny wydaje się komentarz autorstwa jednego z szefów Oddziału III SG, płk. Stanisława Kopańskiego: „Koncepcja dalszych działań wojennych, poza okresem wstępnym ujętych w wytycznych dla dowództw armii, jeżeli istniała w umyśle przyszłego Naczelnego Wodza i znana była jego najbliższym współpracownikom (szefowi sztabu i jego zastępcy), to na pewno nie była ujawniona oddziałowi operacyjnemu. Nie była więc przepracowana przez sztab ani też przepracowana w terenie" ${ }^{\prime 97}$. Wysiłek ludzki i finansowy podjęty przez Polaków był bardzo duży, na miarę możliwości ówczesnego państwa polskiego. Polska odosobniona $\mathrm{w}$ wojnie $\mathrm{z}$ dwoma wrogami nie miała szans na ich pokonanie. Sojusz z zachodnimi aliantami (Anglia i Francja) pokazał, że zamiast działań militarnych prowadzono jedynie tzw. dziwną wojnę.

\title{
Andrzej Wojtaszak
}

\section{USING THE NATURAL ENVIRONMENT IN POLISH PLANS FOR THE FUTURE WAR IN THE THIRTIES OF THE 20 ${ }^{\text {TH }}$ CENTURY}

\begin{abstract}
Summary: In the last decade preceding the outbreak of World War II, the war threat of Poland was perceived by the highest political and military authorities. During the reign of Józef Piłsudski the question was asked: who was the war with? This question asked to the military and political decision makers confirmed three possibilities of the outbreak of the conflict: with Russia, with Germany and with Russia and Germany. The analyzes carried out took into account the use of the natural environment as an important element in the preparation of variants of strategic plans for the future war. Each of the plans took into account the complexity of the defense situation of the state (special, long line of borders, natural obstacles and lack thereof). The Polish military alliances were counted on. The Polish defensive war of 1939 turned out to be a conflict with two aggressors (the Third Reich and the USSR), and with the passivity of our Allies, the chances of victory were only hypothetical. The natural environment may help in the implementation of military action plans, but it does not replace the lack of military capabilities of the army.
\end{abstract}

Keywords: military geography, political geography, war plans, Polish Army.

${ }^{97}$ S. Kopański, Wspomnienia wojenne 1939-1945, Warszawa 1990, s. 16. 